\title{
A zeneoktatásunk kihívásai és nehézségei általános iskolai és gimnáziumi énektanárok nézetei alapján
}

\author{
Pintér Tünde Kornélia \\ Szegedi Tudományegyetem Neveléstudományi Doktori Iskola
}

\begin{abstract}
Absztrakt
Jelen tanulmány célja, hogy meghatározza az iskolai zeneoktatás kihívásait és nehézségeit. 15 zene- és nem zenetagozatos osztályban tanító énektanárral készítettünk interjút. Az eredmények azt mutatták, hogy az ének-zene tantárgy oktatását a megkérdezett tanárok véleménye szerint számos tényező megnehezíti: (1) az időintervallum és a tananyag aránytalansága, (2) a tanulók énekórákhoz füződő közömbös hozzáállása, (3) a diákok zenei tudásának hiányosságai, valamint (4) az énekléshez füződő negatív attitüdje és alacsony zenei önbecsülése, (5) a diák és a tanár közötti generációs különbségek, (6) a pozitív visszajelzések hiánya a tanár számára, illetve (7) a taneszközök és a tantermek felszereltségének hiányosságai. Mindemellett az eredmények megmutatták, hogy a zeneoktatás alapját képező Kodály-módszer kizárólag a zenetagozatos osztályokban tud érvényesülni, ugyanakkor számos esetben ezekben az osztályokban is hanyatló tendenciát mutat a Kodály törekvésein alapuló zenetagozatos ének-zene oktatás helyzete és presztízse.
\end{abstract}

Kulcsszavak: ének-zene, énektanár, interjú, attitűd, Kodály-módszer

\section{Elméleti háttér}

Az elmúlt évtizedekben a zenepedagógusok egyre nagyobb figyelmet fordítanak az iskolai ének-zene tantárgy helyzetének tanulmányozására, amely során rámutattak az ének-zenének az iskolai tantárgyak között betöltött alárendelt szerepére és presztízsére (Csíkos, 2012; L. Nagy, 2003; Pintér, 2018). Az elözetes tanulmányok kimutatták, hogy amíg a tanulók bizonyos tantárgyak - mint például az idegen nyelvek és/vagy a testnevelés - tanulásához pozitívan viszonyulnak, addig az ének-zenét az egyik legkevésbé népszerü iskolai tantárgynak tekintik (Dohány, 2013; Pintér, 2020). A kutatások alátámasztották, hogy a tanulók többsége az ének-zene órákat a közönyhöz és az unalomhoz társítja, míg a zenei élmények kevésbé részei az óráknak (Dohány, 2009, 2014; Janurik, 2007). Ugyanakkor a tanulók fokozott ellenállást tanúsítanak az éneklés (Pintér, 2017), valamint a klasszikus zene iránt is (Janurik, 2008). 
Előzetes vizsgálatunkban kimutattuk, hogy a tanulók mintegy 80\%-a ellenezte a mindennapos éneklés kezdeményezését, $\mathrm{s}$ a megkérdezett tanulók mindössze 19,5\%-a tanúsított érdeklődést a napi szintű éneklés iránt (Pintér, 2017). A nemek között szignifikáns különbséget fedeztünk fel: a lányok szívesebben énekeltek, mint a fiúk. Janurik Márta és Józsa Krisztián (2018) tanulmányukban alátámasztották, hogy a tanulók kifogásolták az énekléssel, a kottaolvasással, valamint a zenehallgatással töltött zenei tevékenységeket.

Egy másik vizsgálatunkban a tanulók negatív attitüdje a tanulók alacsony önbecsülésével, valamint a tananyaggal kapcsolatos elvárásaikkal és a zenetanulásról alkotott nézeteikkel mutatott összefüggést (Pintér, 2020). Az énekórai tevékenységek tekintetében a megkérdezett zene- és nem zenetagozatos tanulók a zenehallgatást nevezték meg az énekórák legkedvesebb foglalkozásának. Ugyanakkor a tanulók alacsony zenei önbecsülése ellenére a diákok számos esetben érintették az énekléssel töltött idő fontosságát is, azonban a tagozatok között jelentős különbségeket tapasztaltunk a zenetagozatos tanulók nagyobb arányára vonatkozóan.

A tanulók saját zenei adottságaikról és képességeikről alkotott alacsony önmegítélése ellenére, a diákok többsége a zenei alapismeretek megszerzését, az éneklést és a zenei élmények átélését tartották az ének-zene órák három legfontosabb feladatának. Ugyanakkor az eredmények rávilágítottak arra is, hogy a tanulók a zenei ismeretek megszerzését (különösen a zenetörténet, a klasszikus zenei szemelvények és a népdalkincs megismerését) a zene hagyományőrző szerepével azonosították (Pintér \& Csíkos, 2020).

Dohány Gabriella (2014) tanulmányában szintén alátámasztotta, hogy a gimnáziumi és szakközépiskolás tanulók az ének-zene órákon elsősorban az élmények átélését részesítik előnyben a tanulással és a zenei alapismeretek elsajátításával szemben. Azonban az előzetes kutatások a zenei élmények hiányára hívták fel a figyelmet. Janurik Márta (2007) kutatásában megállapította, hogy a 7. évfolyamos tanulók jelentősen több szorongást élnek át az énekórán, mint a matematika órákon. Ugyanakkor a Waldorf-iskolákba járó tanulók általánosságban véve több zenei élményben részesülnek, mint a többségi iskolákba járó diákok (Janurik \& Pethő, 2009). Mindeközben Janurik Márta vizsgálatában (2008) megállapította, hogy a tanulók klasszikus zenével való találkozásának szinte kizárólagos színterét az iskola jelenti, míg az otthoni zenei környezet korántsem képes megfelelő komolyzenei élményekben részesíteni gyermekeiket.

További kutatások az iskolai zenei nevelés hanyatlását többek között a gyenge tanárképzéssel, a kiváló muzsikusok és zenetanárok alacsony létszámával, az ének-zene tantárgy alacsony óraszámával, valamint az elavult zenei tananyag és a tanításhoz szükséges taneszközök hiányával hozták összefüggésbe (L. Nagy, 2002; Csengery, 2014). L. Nagy Katalin (2003) tanulmányában kérdőíves módszer segítségével ének-zene tárgyat tanító pedagógusok nézeteit vizsgálta meg az iskolai zenei nevelés helyzetének felmérése céljából. A kutatásban résztvevő tanárok az ének-zene oktatás legsúlyosabb prob- 
lémái között a rendelkezésre álló időkeret és a tananyag aránytalanságát, a tanulók közömbösségét és a tárgyi eszközök hiányát nevezték meg. Ugyanakkor a vizsgálat kimutatta, hogy az ének-zene kedvezőtlen megítélése nem mutat összefüggést a tanárok által megemlített nehezítő tényezőkkel.

Ezen túlmenően a kutatás kitért a zenei tananyaggal, tankönyvvel és taneszközökkel kapcsolatos problémák feltárására is, L. Nagy Katalin kimutatta, hogy a megkérdezett tanárok többsége a zenei tevékenységek (éneklés és zenehallgatás) arányának bővítését javasolta, míg az elméleti részek tanítására (például zeneelméletre és zenetörténetre) kevesebb időt szánnának. A tankönyvek tekintetében a kutatásban résztvevő tanárok a tanulhatóságot tartották a legfontosabb tulajdonságjegynek, amely igazodik a tanulók képességeihez és életkorához, míg a tankönyvcsaládok szempontjából a pedagógusok elsősorban azokat a jól bevált tankönyveket alkalmazták legszívesebben az énekórán, amelyeket a korábbi képzéseik és tanulmányaik során behatóbban megismerhettek. A taneszközök iránti igények elsősorban a hangszerek és hanganyagok beszerzését érintették.

További kihívást jelent a zeneoktatásunk alapját képező Kodály-módszer és annak alapelveinek követése és megvalósítása az énekórák folyamán. Jóllehet korábban több kutató is kifejtette, hogy a Kodály-koncepció didaktikai szempontból - a részletes, módszertani összefoglaló hiányában - nem tekinthető módszernek (Dohány, 2014). A koncepció legfontosabb alapelveit Kodály összegyüjtött írásaiból, leveleiből és nyilatkozataiból ismerjük (Bónis, 2007). Gönczy (2009) felhívja a figyelmet a Kodály-koncepció részletes, kidolgozott módszertanának, köztük a fogalmi térkép, valamint az idő intervallum meghatározásának hiányaira, amelyek a Kodály-módszer iskolai gyakorlatban történő alkalmazásának nehézségeit vetik fel. Kodály zenepedagógiai koncepcióját - a módszertani kidolgozottságának hiánya ellenére mind a hazai, mind a nemzetközi szakirodalom Kodály-módszerként említi (Szőnyi, 1971; Türkmen \& Göncü, 2018), ezért jelen tanulmányban szintén a Kodály módszer elnevezést kívánjuk alkalmazni.

A Nemzeti alaptanterv minden iskolai évfolyamra kiterjedően Kodály zenepedagógiai irányelveire alapozva írja elő az iskolai zenei nevelés célját és fejlesztési területeit (Nemzeti alaptanterv, 2020). A Nemzeti alaptanterv zenei nevelést érintő célkitűzései kiemelt szerepet tulajdonítanak a zenei képességek és készségek fejlesztésének, valamint a zenei ismeretanyag élményszerü tolmácsolásának és átadásának. Azonban az előzetes kutatások a zenei élmények hiányára mutatnak rá, miszerint az énekórákon a zenei élményeket több esetben az unalom, az apátia, a stressz és a szorongás váltja fel (Janurik, 2007; Janurik \& Pethő, 2009).

A zenei élmények és a nagy mennyiségű zenei tananyag együttes biztosítása jelentős kihívás elé állítja az ének-zenét tanító tanárok többségét. Az óraszámok tekintetében a tanulók az ének-zenét 1-4. évfolyamig heti 2 órában, majd 5. osztálytól 10. (illetve 12. évfolyamig) mindössze heti 1 órában tanulják. Ennek megfelelően a tanároknak az általános iskola felső tagozatán 
és a gimnáziumban heti egy alkalom áll rendelkezésre a Nemzeti alaptantervben kitüzött fejlesztési területek és kompetenciák fejlesztésére. Ugyanakkor az új Nemzeti alaptanterv 2020. szeptemberétől az ének-zene tantárgy oktatását az általános iskola 5. évfolyamán heti 2 órára módosítja. Mindeközben a speciális ének-zene tagozattal rendelkező iskolákban a gyerekek az ének-zenét emelt óraszámban, heti 3-4 órában tanulják, valamint énekkari foglalkozásokon vesznek részt.

Az iskolai zeneoktatás helyzetét - köztük a speciális ének-zene tagozatos iskolák jövőképét - szintén erőteljesen befolyásolja a szabad iskolaválasztás lehetősége is, amelynek hatására a tehetősebb szülők igyekeznek gyermeküket az idegen nyelvi képzést vagy a különböző közismereti tantárgyak (köztük a humán és a reál tantárgyak) képzését előtérbe helyező iskolákba íratni. Mindez a művészeti tantárgyak (avagy készségtantárgyak) háttérbe szorulását hozta magával. Egyre kevesebb tanuló jelentkezik ének-zene tagozatos osztályba, holott a kutatások alátámasztották, hogy az intenzív zenetanulás jótékony hatással van a tanulók intelligenciájára, illetve a kognitív, perszonális és szociális képességeik fejlődésére. Egy előzetes vizsgálatunkban a zenetagozatos osztályok számának hanyatló állapotát a tagozaton tanító énektanárok is alátámasztották, miszerint jelentősen csökken a zenetagozatos osztályokba jelentkező gyermekek száma (Pintér, 2020). Laczó (2010) kiemeli, hogy az iskolai nevelést - így a zenei nevelést is - alapvetően megnehezíti a technológiai fejlődés és a világháló megjelenése, amelyek jelentősen csökkentik a tanulók koncentrációs képességét.

A zeneoktatás helyzetét szintén meghatározza az énektanárképzés színvonala. Szabó (1996) tanulmányában beszámol, hogy a tanárképzés elsősorban a vezénylési technika elsajátítására fordít döntő szerepet, míg a gyermekek hangjának képzését szolgáló ismeretek átadása háttérbe szorul. Asztalos Andrea kutatásában (2018) a gyermekek hangképzését szolgáló beéneklő gyakorlatok típusait és a gyakorlatok alkalmazásának gyakoriságát vizsgálta, amely során megállapította, hogy azokban az iskolákban, ahol gyakorta elmaradtak az énekhang bemelegítését szolgáló gyakorlatok, a tanulók több hangképzési problémával küzdöttek, mint azok a tanulók, akik rendszeresen bemelegítették a hangjukat az énektanáruk irányításával. Mindamellett Bruckner Adrienne (1999) az énektanárok énekhangjának magas szintű képzésére és karbantartására hívta fel a figyelmet, amely erőteljesen meghatározza a tanulók helyes hangképzésének esélyeit.

A tanárok munkáját sok esetben megnehezítheti a különböző kulturális és szociális-ökonómiai háttérrel rendelkező gyermekek nevelése. Az előzetes kutatások bebizonyították, hogy a családok aligha tudják biztosítani a gyermek zenei neveléséhez szükséges tárgyi eszközöket, mint például a hangszerek és komolyzenei hangfelvételek beszerzését (Janurik, 2008; Turmezeyné \& Balogh, 2009), ugyanakkor a családban zajló közös zenei tevékenységek is jelentősen háttérbe szorulnak (Dohány, 2013). Egy korábbi tanulmányunk- 
ban zenetagozatos és nem zenetagozatos tanulók otthoni zenei környezetét vizsgáltuk, amely során megállapítottuk, hogy a családban történő aktív zenei tevékenységek elsősorban a zenész családokban fordulnak elő, míg a többségi (nem zenetagozatos tanulók) otthonában rendkívül elenyészőek a közös zenei tevékenységek, amelyek a passzív zenei tevékenységekre (mint például a zenei TV-müsorok fogyasztására) korlátozódnak (Pintér \& Csíkos, 2020).

Mindemellett a zeneoktatás zavartalanságát a tanár és diák közötti generációs különbségek is veszélyeztethetik. Napjainkban a generációkutatások öt különböző generációt különböztetnek meg: a baby boomerek, valamint az X, Y, Z és az úgynevezett alfa generációkat (Pál és Törőcsik, 2013). Mannheim (1969) szerint egy korcsoportot akkor tekinthetünk közös generációnak, ha valamely közös tulajdonság, nemzedéki tudat, valamint közösségi jegy jellemzi őket (idézi Nagy \& Kölcsey, 2017, p. 20). A jelenleg iskolába járó tanulók egy része a $\mathrm{Z}$ generáció, másik része az úgynevezett alfa generációhoz tartozik, akik számottevő tulajdonságjegyekben különböznek az őket tanító tanáraiktól, illetve az előző generációktól is. A kutatások azt bizonyítják, hogy a mai gyerekek a megnövekedett információgyűjtés és -kezelés mellett az iskolai tanulmányaikat, szórakozási szokásaikat, valamint a barátságok kialakítását és fenntartását tekintve is eltérnek az előző nemzedék gyerekeitől (Tóbi, 2013). Korunk gyermekei máshogyan tanulnak; digitális készségük meglehetősen korán kialakul, ugyanakkor ingerküszöbük rendkívül magas, ezáltal a koncentráció és a figyelem fenntartása sok esetben nehézséget okoz számukra (Tari, 2010, 2011). Ebből kifolyólag az énektanárnak a zenei készségfejlesztésen és a zenei élmények biztosításán túlmenően az említett tulajdonságjegyekkel rendelkező gyermekekhez történő alkalmazkodása is nélkülözhetetlenné válik az énekórákon.

\section{A kutatás célja}

Jelen kutatás célja, hogy megvizsgálja az ének-zene tantárgy helyzetét, valamint hogy feltárja milyen kihívásokkal és nehézségekkel küzd napjaink zeneoktatása az ének-zenét tanító tanárok véleménye szerint. A kutatás során az iskolai zenei nevelés helyzetét (1) az oktatást megnehezítő tényezők feltérképezésére, (2) a zenei tananyaggal kapcsolatos nézetekre, (3) az ének-zene tantárgyból elvárt tudásszint mélységére és a számonkérés szigorúságára, valamint (4) a kodályi alapelvek követésére és alkalmazására vonatkozóan vizsgáltuk meg.

\section{A minta és módszerek}

A kutatás során bizonyos jelenségek mélyebb megértését tüztük ki célul, melyet induktív kutatási stratégia, azaz interjú módszer segítségével kívántunk megközelíteni (Szokolszky, 2004). A válaszadók kiválasztása során célunk az ének-zene tantárgyat tanító pedagógusok megkérdezése volt. A mintavétel 
egységét a megyeszékhelyeken (Pest, Csongrád-Csanád, Hajdú-Bihar, Szabolcs-Szatmár-Bereg és Baranya megyékben) müködő zenetagozatos és nem zenetagozatos iskolák adták. A településtípusok és regionális különbségek összehasonlítására nem törekedtünk. A mintavétel során részben a vizsgálat kvalitatív jellegéből fakadóan (Sántha, 2007; Szokolszky, 2004), másrészt a hazai (Tóth, 2015) és nemzetközi (Wayman, 2004) vizsgálatokban alkalmazott mintanagysághoz való alkalmazkodás kapcsán jelen kutatásban nem törekedtünk nagy minta kialakítására. A vizsgálat középpontjában a zeneoktatás eredményességét megnehezítő nehézségek és kihívások megértése és feltárása állt.

A kiválasztott iskolák intézményvezetőinek engedélyezését követően a kutatásban résztvevő tanárokat személyesen és/vagy hivatalos levélben kerestük meg az interjú időpontok egyeztetése végett. A vizsgálatok során öszszesen 11 iskola 15 ének-zenét tanító tanárával (köztük 3 nevelőtanárral, 6 zenetagozaton és 6 zene- és/vagy nem zenetagozaton tevékenykedő pedagógussal) készítettünk félig strukturált interjút, akik képzettségüknek megfelelően 1-10. (11-12.) osztályokban tanították az ének-zenét. Némely tanár az adott iskolában zene és nem zenetagozatos osztályokban egyaránt tanított, ebből kifolyólag a zenetagozat helyzetéről általános iskolában 5 pedagógus, a gimnáziumban 3 ének-zene tanár számolt be. Míg az ének-zene megítélését a nem zenetagozatos osztályokban alsó tagozaton 3 nevelőtanár, felső tagozaton 5 tanár, a gimnáziumban további 5 pedagógus fejtette ki. A kutatásban résztvevő pedagógusok átlagéletkora 45,86 év. Nemek tekintetében 9 nő és 6 férfi tanár vett részt a vizsgálatban. A válaszadók közül a pedagógiai életpályamodell alapján 9 tanár Pedagógus I., míg 6 pedagógus Pedagógus II. fokozattal rendelkezett. Az interjúk előre kidolgozott interjúkérdések alapján készültek, s a személyes találkozás alkalmával hozzávetőlegesen 1-1,5 órát vettek igénybe. Az adatgyüjtést egy személy végezte.

A kutatás érvényességének (validitás) és megbízhatóságának (reliabilitás) biztosítása érdekében az interjúk hanganyagai a válaszadók beleegyezését követően rögzítésre kerültek, majd azokat írásos formában dokumentáltuk (Böddi et al., 2015). Továbbá az interjúkérdések megalkotásakor az interjúalanyok a kutatás kérdéseiről való részletes informálásának mellőzésére törekedtünk, mint például arra a kutatási kérdésünkre vonatkozóan, hogy a tanárok mennyire veszik szigorúan a kodályi alapelvek megvalósítását az iskolai ének-zene órákon, a meginterjúvolt pedagógusok számára a következő kérdést tettük fel az interjúk során: „,Milyen zenepedagógiai módszereket ismer és alkalmaz az énekórán?” Az eredmények elemzése során a kategóriaalkotás induktív módon történt (Sántha, 2007, 2009; Szokolszky, 2004). A kapott válaszokat papír-ceruza módszer segítségével az interjúalanyok által érintett témák gyakorisága alapján kategorizáltuk. 


\section{A tanárokkal készített interjúk kérdései}

A kutatás során a következő kérdésekre kerestük a választ: (1) milyen mindennapi problémákkal találkoznak az ének-zene tanítás során, (2) hogyan vélekednek a zenei tananyag felépítéséről, nehézségi szintjéről és hasznosságáról, valamint (3) az ének-zenéből történő számonkérés szigorúságáról, továbbá (4) a kodályi alapelvek iskolai gyakorlatban történő megvalósításának lehetőségeiről?

Ennek megfelelően az interjúkérdéseket az imént megnevezett témakörök mentén tettük fel a kutatásban résztvevő tanárok számára:

1. A zeneoktatás során felgyülemlő problémák összesítése:

1.1. Milyen mindennapi problémákkal találkozik az ének-zene tanítás során?

2. A zenei tananyag elemzése:

2.1. Van-e olyan része a zenei tananyagnak, amely nem mindenki számára megtanulható?

2.2. Van-e olyan része a zenei tananyagnak, amely nem mindenki számára hasznos?

2.3. Van-e olyan része a zenei tananyagnak, amelynek elsajátítása nélkülözhetetlen a tanuló számára?

2.4. Van-e olyan része a zenei tananyagnak, amelynek módosítását célszerünek találná?

2.5. Mit gondol a könnyűzene iskolai tanításáról?

3. A számonkérés szigorúsága:

3.1. Van-e olyan része a zenei tananyagnak, amelynek nem teljesítése esetén fennáll a buktatás lehetősége?

4. A Kodály-módszer megvalósítása az iskolai gyakorlatban:

4.1. Milyen zenepedagógiai módszereket ismer, valamint melyeket alkalmazza az énekóra keretein belül?

\section{A kutatás hipotézisei}

A kutatást megelőzően abból indultunk ki, hogy az iskolai zeneoktatás alapját képező Kodály-módszer aligha tud érvényesülni a mai oktatásban, amit erőteljesen befolyásol a tantárgy alacsony óraszáma (Gönczy, 2009; Janurik, 2008). Felvetődik a kérdés, mennyire vegyük szigorúan a kodályi elveket az énekórai folyamatok alatt. Jóllehet a Kodály-koncepció elsősorban a speciális ének-zenei osztályokban tud érvényesülni, míg a nem zenei osztályokban heti 1-2 énekóra mellett kevésbé teljesíthető a kodályi alapelvek megvalósítása. Ennek ellenére a Nemzeti alaptanterv és a kerettantervek a kodályi elveken alapuló célkitűzéseket minden évfolyamra kiterjesztik.

Az interjúk lebonyolítása előtt feltételeztük, hogy az énektanárok véleménye szerint az ének-zene (mint készségtantárgy) alacsony presztízsnek örvend az iskolai tantárgyak között. Továbbá feltételeztük, hogy a zeneok- 
tatás eredményességét számos tényező megnehezíti, mint például az idő és a tananyag aránytalansága, a tanulók énekórák iránti érdektelensége, a mai generációhoz való alkalmazkodás, az elavult taneszközök, a nagy mennyiségü zenei tananyag, valamint a műveltségátadás és a zenei élmények együttes biztosítása. Feltételeztük, hogy a tanárok mind a készségfejlesztést, mind a zenei élmények nyújtását fontosnak és hasznosnak tartják az énekórák folyamán.

Ezen túlmenően feltételeztük, hogy a tanárok többsége szorgalmazza a zenei tananyag módosítását, azon belül a népdalok és zenehallgatási anyagok bővítését a zenetörténeti, szolfézs- és zeneelméleti ismeretekre szánt idő csökkentésével (L. Nagy, 2003). Továbbá feltételeztük, hogy a tanárok Kodály szellemiségét követve a zenei képességek és készségek fejlesztésére, a zenei írás-olvasás elsajátítására, az értékes zene közvetítésére, a zenei hagyományok ápolására, az aktív zenei tevékenységekre; köztük az éneklésre és zenehallgatásra, valamint a zenetörténeti ismeretek biztosítására egyaránt koncentrálnak, azonban a kitűzött célok megvalósítását alapvetően hátráltatja az ének-zene alacsony óraszáma.

\section{A tanári interjúk eredményei}

\section{Mindennapos problémák és kihívások az énekórán}

Az interjú során a kutatásban résztvevő tanárokat arra kértük, hogy osszák meg véleményüket és személyes tapasztalataikat arról, milyen mindennapos problémák nehezítik meg az iskolai énekórák megtartását. A kutatást megelözően az ének-zene oktatást nehezítő problémák mögött egyidejűleg számos tényezőt feltételeztünk. Az eredmények alátámasztották hipotézisünket. A megkérdezett tanárok az iskolai ének-zene tanítást megnehezítő problémák között a következő tényezőket érintették: az óraszám és a tananyag aránytalansága, a tanulók közömbös hozzáállása, a tanulók tudásbeli hiányosságai, a diákok énekléssel kapcsolatos lelkesedése és alacsony önbecsülése, a tanár és diák közötti generációs problémák, a pozitív visszacsatolás hiánya a tanár számára, a fegyelmezetlenség kezelése, a tanár széleskörü tájékozottságában rejlő kihívások, magas osztálylétszámok, a szabad tankönyvválasztás hiánya, valamint egyéb infrastruktúrából eredő nehézségek a tanterem kihasználhatóságára vonatkozóan. Az eredményeket az 1. táblázatban szemléltetjük. 
1. táblázat

Az ének-zene oktatást megnehezítö problémák a tanárok véleménye alapján

\begin{tabular}{|l|c|c|c|}
\hline \multicolumn{1}{|c|}{ Problémák és kihívások } & $\begin{array}{c}\text { Zenetago- } \\
\text { zat } \\
\text { (N) }\end{array}$ & $\begin{array}{c}\text { Nem ze- } \\
\text { netagozat } \\
\text { (N) }\end{array}$ & $\begin{array}{c}\text { Összesen } \\
\text { (N) }\end{array}$ \\
\hline Az óraszám és a tananyag aránytalansága & 2 & 5 & 7 \\
\hline $\begin{array}{l}\text { A tanulók zenetanuláshoz füződő közömbös- } \\
\text { sége, hozzáállása (attitüd) }\end{array}$ & 4 & 3 & 7 \\
\hline $\begin{array}{l}\text { A tanulók tudásbeli különbségei és hiányos- } \\
\text { ságai }\end{array}$ & 3 & 4 & 7 \\
\hline $\begin{array}{l}\text { A tanulók énekléshez füződő negatív attitüdje } \\
\text { és alacsony önbecsülése }\end{array}$ & 0 & 4 & 4 \\
\hline Tanár és diák közötti generációs problémák & 2 & 0 & 5 \\
\hline $\begin{array}{l}\text { A pozitív visszacsatolás hiánya a tanár szá- } \\
\text { mára }\end{array}$ & 1 & 2 & 3 \\
\hline $\begin{array}{l}\text { A tanulók fegyelmezetlenségének kezelése az } \\
\text { énekórán }\end{array}$ & 1 & 3 & 4 \\
\hline A tanár tájékozottsága és múveltsége & 1 & 2 & 3 \\
\hline $\begin{array}{l}\text { Tárgyi eszközök hiánya } \\
\text { kzaktanterem hiánya }\end{array}$ & 0 & 3 & 3 \\
\hline Szabad tákok) & 0 & 2 & 2 \\
\hline
\end{tabular}

A problémák felsorakoztatása során a legtöbb tanár az ének-zene tantárgy alacsony óraszámát, azon belül az időkeret és a tananyag aránytalanságát, valamint a tanulók énekórákhoz, zenetanuláshoz és énekléshez füződő negatív hozzáállását és alacsony zenei önbecsülését, illetve az előzetes zenei tudásuk hiányosságait kifogásolták.

Az eredmények azt igazolták, hogy valamennyi tényező egymással szoros összefüggést mutat. Az alacsony óraszám hatására homályossá válnak a kitűzött célok, köztük a nagy mennyiségű zenei műveltséganyag és a ze- 
nei élmények biztosítása, valamint a rájuk szánt idő beosztása, amit tovább nehezít a tanulók tudásbeli hiányosságainak pótlása. A pedagógusinterjúk során az iskolai zeneoktatás problémáiról és kihívásairól az egyik legátfogóbb helyzetjelentést egy gimnázium ének és normál osztályaiban egyaránt tevékenykedő ének-zene szakos tanárnő fogalmazta meg.

„Az utóbbi évtized alatt erőteljesen devalválódott az ének presztízse; egyre kevesebb tanuló szándékozik énektagozaton továbbtanulni, helyette sokan a természettudományos képzéseket részesítik előnyben. Ugyanakkor a gimnáziumban alapvetően megváltoznak a célkitüzések is; a tananyag rendkívül zsúfolt, miközben a tanulók jelentős része hiányos zenei tudással érkezik a gimnáziumba. Az énekórák nagyrészét a zenei ismeretek pótlása, valamint az alapvető készségek fejlesztése és javítása veszi el, s a legkevesebb idő a zenei élmények nyújtására jut. Többek között komoly nehézséget jelent a tanulók számára az együtt éneklés, nem tudnak szolmizálni és kottát olvasni. Mikor megkérdezem a tanítványokat, hogyan jellemeznék az általános iskolai énekórákat, a tanulók többsége a semmittevést nevezi meg. Mindezek hatására az énektanár folyamatosan veszíti el ambícióját és motiváltságát, hogy nem tud mit csinálni heti egy órában a gyerekekkel. Ugyanakkor a tanulók is túlterheltek a számottevő lexikális tudásanyag elsajátítása kapcsán, miközben képességfejlesztésre valójában nem áll rendelkezésre kellö idő." (55 éves gimnáziumi ének-zene tanár)

A pedagógusinterjúból kirajzolódik, hogy az ének-zene presztízscsökkenése elsősorban a tanulók zenetanulás iránti érdektelenségében mutatkozik meg. Ezzel szemben az oktatás nehézségeit az időkeret és a tananyag összeférhetetlensége, valamint a tanulók tudásbeli hiányosságai és alacsony zenei önbecsülése adják. Az eredmények ismertetését a fejezet további részében a tanulók hozzáállása, tudásbeli hiányosságai, valamint az énekléshez füződő attitűdjének szempontjából közelítjük meg.

\section{A tanulók hozzáállása}

A tanulók zenetanuláshoz füződő közömbössége a tanári visszajelzések alapján mindkét tagozaton jellemző volt. A zenetagozatos osztályokban tevékenykedő pedagógusok elsősorban a tagozatra jelentkező gyermekek lemorzsolódását említették, amely során számos esetben hangsúlyozták Kodály zenepedagógiai örökségének háttérbe szorulását a tanulók és szülők részéről az iskolaválasztás során.

„Számos esetben azt tapasztalom, hogy a szülők nem Kodály szellemisége és öröksége kapcsán íratják be gyermeküket ebbe a (zenetagozatos) iskolába, hanem különféle tényezőket vesznek figyelembe, mint például szép, felújított iskola, valamint kulturált tanulói közösség jellemzi az intézményt." (50 éves ének-zene tanár) 
„A zenetagozaton azt tapasztalom, hogy nagyon sok gyereket szülői nyomásra íratják be zenetagozatra, mint például az alsó tagozaton tanítót választ a szülő, s nem a zene iránti elkötelezettség kapcsán jár ide a gyermek. Ezek a tanulók a zene iránti közömbösségükből fakadóan mindeközben folyamatosan lemaradnak társaiktól mind zenei tudásuk, mind képességeik fejlődését tekintve." (47 éves ének-zene tanár)

„Ebben az iskolában egy lehulló félben lévő zenetagozat müködik, ami azt jelenti, hogy fontosnak van tartva; az alapvető zenei kötelezettségeket teljesíti, de tulajdonképpen ez egy lefelé ágazó tagozat; egyre kevesebb az érdeklődés, egyre csökken a gyerekek száma, nem jönnek el annyian felvételizni, helyette mindenki kéttannyelvű angolra és testnevelésre akar menni." (30 éves ének-zene tanár)

A nem zenetagozatos osztályokban tanító tanárok többsége sok esetben a tanulók érdektelenségéről számolt be, ami egyúttal az énektanárok lelkesedésének csökkenését eredményezi. A nem zenetagozatos tanulók énekórákhoz való hozzáállását két általános iskolai és két gimnáziumi énektanár szemszögéből mutatjuk be.

„Az általános iskola 5. évfolyamán vannak olyan tanulók, akik érdeklődőek, jó jegyeik vannak, őket el lehet varázsolni. Az ő esetükben azt tapasztalom, ha élményszerüen tárom eléjük a zene világát, a tanulók is nyitottak az órák felé, őket még lehet motiválni. Ezt követően a 6. osztálytól jön a váltás; a csoportnyomás, a kamaszkor okozta változások, amikor rendkívül ellenállóak lesznek a diákok. Ezzel szemben a 8. évfolyamos nem tagozatos tanulók ismét érdeklődőek, különösen a népdalok háttere iránt, velük nagyon sokat lehet beszélgetni." (47 éves ének-zene tanár)

„A tanulók egyáltalán nem érdeklődnek az ének iránt, kizárólag a magyar és a matek iránt. A zenét sok esetben háttérzenének hallgatják. Ugyanakkor már az sem igaz, hogy 'ha a társam játszik hangszeren, akkor én is elkezdek tanulni a zeneiskolában.' (49 éves ének-zene tanár)

„Az énekórák zavartalanságát elsősorban a tanulók közömbössége nehezíti meg... Amit én nagyon fontosnak tartok, az a befogadói attitűd megléte, amely számos esetben hiányzik a tanulóknál." (52 éves ének-zene tanár)

„A tanulók szerint a jó zene csak könnyüzene lehet.” (60 éves ének-zene tanár)

Az eredmények rávilágítanak arra, hogy a tanulók hozzáállása egyes énekzene tagozatos osztályokban sem kielégítő, míg a nem tagozatos évfolyamokon a diákok többsége közömbösen viszonyul az iskolai ének-zene órákhoz, ami alapvetően kihívás elé állítja a tárgyat oktató tanárokat. 


\section{A tanulók elözetes zenei tudásából fakadó problémák}

Az ének-zene oktatást megnehezítő problémák megbeszélése során a megkérdezett tanárok számos esetben érintették a diákok előzetes zenei műveltségének és ismereteinek hiányosságait. Az interjúk során mintegy 7 énektanár nyilatkozta, hogy a tanulók egy része hiányos zenei alapismeretekkel érkezik már az alsó tagozatból a felső tagozatba, illetve az általános iskolából a gimnáziumba. Az eredmények rámutatnak arra, hogy a tanulók különböző zenei tudásának enyhítése és javítása sok esetben megoldhatatlan feladatnak bizonyul az ének-zene tantárgy heti egy óraszámában. Ennek következtében a tanárok az alacsony óraszámban az aktuális, új tananyag leadása, az élményszerzést szolgáló aktív zenei tevékenységek mellett a tanulók zenei alapismereteinek pótlására is kellő időt kell szánniuk. A tanulók tudásbeli hiányosságaira mind a zene-, mind a nem zenetagozatos osztályokban fény derült. Az eredményeket nem tagozatos és egy zenetagozatos osztályban tanító tanárok nyilatkozataival szemléltetjük.

„Az alsó tagozatról a tanulók számos esetben az alapvető zenei alapismeretek hiányában érkeznek a felső tagozatba. A gyermekek nem ismerik a hangszereket, a hangközöket, tehát már általános iskola alsó tagozatán lemaradnak, ebből kifolyólag az énektanárra többletfeladat hárul; heti egy óraszámban az énektanárnak az aktuális tananyag leadása mellett a zenei hiányosságok pótlására is koncentrálnia kell. Ezért is tartom fontosnak, hogy kizárólag ének-zene szakos tanár taníthassa az éneket." (49 éves ének-zene tanár)

„Számtalanszor tudásbeli hiányosságok nehezítik az órákat, melyek kapcsán a legnagyobb problémát az okozza, hogy nagyon sok zenei képességet kisgyermekkorban lehet elsajátítani, s később - különösen a gimnáziumi évek során - olykor lehetetlen bepótolni." (27 éves ének-zene tanár)

\section{Alacsony önbecsülés és énekléshez füzödő negativ attitüdök}

A megkérdezett énektanárok elmondása alapján a tanulók énekórákkal kapcsolatos érdektelensége és zenei ismereteik hiányosságai mellett az énekórákon sok esetben nehézséget okoz a tanulók alacsony zenei önbecsülése is, amely elsősorban az éneklési tevékenységek során mutatkozik meg. Az eredményekből arra következtettünk, hogy a tanulókkal kapcsolatos három probléma (attitűd, tudásbeli hiányosságok és az alacsony önbecsülés) szoros összefüggésben vannak egymással.

Az eredményeinket a legelső tanári interjúban nyilatkozott gimnáziumi ének-zene tanár is alátámasztotta, miszerint a tanulók hiányosságainak pótlása az órák nagyrészét elveszi, s nincs idő élményszerzésre. Ennek következtében a tanulók nem jutnak el az élményig, ugyanakkor hiányos zenei ismeretük miatt nincs sikerélményük az énekórai tevékenységekben. Mindemellett 
egy másik ének-zene tanár rávilágított arra, hogy a tanulók tudásából fakadó problémákat tovább súlyosbítja a kamaszkorral jelentkező csoportnyomás és a társak közötti versengés is, melyek a társak előtti éneklés elutasításához vezetnek. Az eredményeket egy harmadik ének-zene tanár is megerősítette, aki a tanulók énekléshez füződő alacsony önbecsülését a társak véleményének fontosságával hozta összefüggésbe.

„Az általam tanított (gimnáziumi) osztályokban sokan félnek énekelni, noha van jó hangjuk, és tisztán énekelnek, de olyan halkan, hogy egy méterrel arrébb nem hallatszik. Azt tapasztalom, hogy a tanulók körében nem sikk ma már az éneklés... Nem dicsekednek ezzel a többi osztálytárs elött, mert félnek, hogy kinevetik őket, illetve rossz színben tünnek fel társaik előtt. Ugyanakkor mikor párban feleltetem őket vagy megengedem, hogy ketten énekeljenek nekem valamit, akkor egyből bátrabbak. Hasonlót tapasztalok, mikor kánonban tapsoltatom őket, akkor is viszonylag bátrabbak. Ugyanakkor már a tapsnál is bátrabbak a gyerekek, mint éneklés esetén. Ezzel szemben azok a tanulók, akik magabiztosak és bíznak önmagukban, bátran jelentkeznek az ötösért önállóan." (43 éves ének-zene tanár)

A tanulók énekléshez füződő alacsony önmegítélését elsősorban a nem zenetagozatos osztályokban tanító tanárok beszámolóiban tapasztaltuk. A zenetagozatos osztályokban tevékenykedő tanárok közül mindössze egy tanár jelezte a mutáló diákokkal való foglalkozás nehézségeit.

„Felső tagozaton, mikor a tanulók mutálni kezdenek, sok esetben problémát jelent, hogy hogyan kötöd le a gyermeket, akinek például az orvos mondja, hogy nem énekelhet, s a gyermek hozza az órára az orvosi igazolást. Nyilvánvalóan én magam is mondom az adott gyermeknek, hogy ne énekeljen, mivel nagyon veszélyes a hangjára nézve." (47 éves ének-zene tanár)

Az eredmények azt mutatják, hogy a tanulók alacsony önbecsülése elsősorban a nem zenetagozatos osztályokban jellemző, míg az aktívan énekkarban éneklő zenetagozatos osztályokban a mutálással kapcsolatos nehézségek kezelése nehezíti meg a tanárok munkáját.

\section{Generációs különbségek: a mai gyermekek jellemzése}

A megkérdezett tanárok szerint a generációs különbségek elsősorban a tanulók - részben a technológiai változások hatására kialakult - megnövekedett ingerküszöbének szintjében, a problémamegoldó-képességük hiányában, valamint a mérsékelt szociális kommunikatív kompetenciájukban mutatkozik meg. Ugyanakkor a tanárok hozzátették, hogy számottevő iskolán kívüli kulturális és zenei hatások is befolyásolják a tanulók zenei ízlését, melyek szembe mennek a hagyományokat és a klasszikus értékeket közvetítő iskolai zeneoktatás célkitűzéseivel. 
„Úgy vélem, hogy a mai gyermekeknek rendkívül magas az ingerküszöbe. Ebből kifolyólag átlagos és hagyományos módszerekkel elég nehéz boldogulni. Természetesen más kérdés, hogy mi a célja a tanárnak a tanítványaival. Amennyiben abban hisz, hogy a gyerekek ének-zene órán elsősorban tudást szerezzenek, akkor bajba kerülhet a tanár, mert olyan eszközöket kell alkalmaznia, amelyek kicsit diktatórikusak lesznek. Ezek bár egyrészt elvezethetnek a tanár céljainak megvalósításához, ellenben más kérdés, hogy vajon szeretni fogják-e a tanulók a zenét. Az énektanárnak azon kellene elgondolkodnia, hogy mi a pontos célja: tudásátadás vagy élményben való részesítés. Én úgy gondolom, hogy mindkettő egyaránt fontos; amennyiben élményben részesíti, akkor biztosíthat tudást is számukra." (46 éves ének-zene tanár)

„Habár ebben az iskolában a tanulók énekórákhoz való hozzáállása rendkívül kimagasló az országos átlaghoz képest, a mindennapos problémákat a tanulók feladatmegoldási képességében, valamint az önállóságuk és problémamegoldó képességeik hiányában tapasztalom. Úgy látom, hogy a tanulók körében sok esetben nincs igény önálló problémamegoldásra, s helyette a tanártól várják a megoldás kulcsát. Ettől függetlenül úgy vélem, hogy rendkívül ügyesek a gyerekek, szépen énekelnek, és nincsenek fegyelmezési problémák sem az énekórák folyamán." (35 éves ének-zene tanár)

\section{A tanári tájékozottsággal kapcsolatos gondolatok}

Az ének-zene tantárgyat tanító pedagógusok széleskörű műveltsége és tájékozottsága alapvetően nem a zeneoktatás problémáit, sokkal inkább a tanárokkal szembeni magasabb elvárásokat és kötelezettségeket veti fel. Az interjúk során három énektanár említette meg a zene transzferhatásaiból fakadó tágabb ismeretek közlésének fontosságát, mint például az ének-zene más iskolai tantárgyakkal való összekapcsolását és a közöttük lévő összefüggések bemutatását az énekórán, melyek a diákok teljes személyiségformálásához járulnak hozzá. Az eredményeket egy általános iskolában és egy gimnáziumban tevékenykedő ének-zene tanár nyilatkozatával szemléltetjük.

„Fontos megjegyezni, hogy a zene segít más tantárgyak tanulásában, fejleszti a gondolkodást és a memóriát, a gyerekek megtanulnak rendszerezni, ezért a zenei készségfejlesztés mellett erre is igyekszem rávezetni őket. Például matematika-ének szakos tanárként a ritmusképleteket a törtek tanításával együtt tanítom." (53 éves, általános iskolai ének-zene tanár)

„Úgy látom, hogy a pedagógusnak felkészültnek kell lenni, a szakmát nagyon tudni kell, majd rendet és fegyelmet tartani. Ugyanakkor nemcsak a szakmát kell tudni, hanem szintézisben kell lenni, tantárgyközi kapcsolatok: történelem, irodalom, akár matematika, más művészeti ágak, mindig valamilyen szinten megemlítésre kerüljenek. Tehát ez ne csak egy ilyen külön tudomány legyen, hanem lássák az összefüggéseket is." (52 éves gimnáziumi ének-zene tanár) 


\section{Pozitív visszacsatolás hiánya a tanár számára}

A tanulók közömbössége az ének-zeneórák iránt alapvetően hatással van az ének-zenét tanító tanárok lelkesedésére és motiváltságára. Némely tanár a problémák összegzése során neheztelően nyilatkozott a tanulók pozitív viszszajelzésének hiányát illetően.

„Annak idején zeneiskolában tanítottam, ahol az alsó tagozatos gyermekek arcán egyből mosoly volt, csillogott a szemük, megöleltek, míg itt az általános iskola felső tagozatán teljesen más, a kamaszgyerek egyszerüen közömbös, fásult és ellenálló. De én azt gondolom, hogy a mag, amit ültetsz, előbb-utóbb úgy is kicsírázik. Nem könnyủ elviselni, hogy ma nem látod az eredményét annak, amit csinálsz." (47 éves ének-zene tanár)

\section{Tanulói fegyelmezetlenséggel kapcsolatos problémák}

A megkérdezett tanárok elmondása szerint az énekórán kisebb számban fordulnak elő fegyelmezési problémák, melyek szoros összefüggésben vannak a kamaszkor megjelenésével és a magas osztálylétszámokkal. A fegyelmezetlenség elsősorban a nem tagozatos osztályokban az általános iskola felső tagozatán, valamint a gimnáziumban jellemzőek, és szintén megnehezítik az iskolai ének-zeneórák folyamatát, és az ének-zenét tanító pedagógusok munkáját.

„Néhány felsős, nem tagozatos osztályban gyakran előfordulnak fegyelmezési problémák. Ezeket leszámítva az általam tanított osztályokban pozitív az ének-zene megítélése." (35 éves ének-zene tanár)

„Az iskola által szervezett közös ifjúsági hangversenyeken folyamatosan a gimnazisták rendetlen, fegyelmezetlen viselkedését tapasztalom. Nem tisztelik a színpadon zenélő művészek munkáját, sem a többi diáktársukat, akik pedig miattuk nem tudják élvezni a koncertet." (60 éves ének-zene tanár)

\section{A tantermek felszereltsége és tárgyi eszközök}

Az eredmények azt mutatják, hogy a zenetanításhoz szükséges tárgyi eszközök, mint például a hangszerek (zongora, ritmushangszerek), a zenehallgatási eszközök, projektor és internetelérhetőség valamennyi iskolában a tanárok számára rendelkezésre állt. Néhány esetben találkoztunk visszásságokkal a tárgyi eszközök beszerzése kapcsán, amely során 2 tanár jelezte, hogy bár rendelkeznek a tanításhoz szükséges eszközökkel, azonban azok beszerzéséről saját maguk gondoskodtak. Ugyanakkor három ének-zene tanár (köztük 1 nem zenetagozatos általános iskolai tanár, 2 zenetagozatos gimnáziumi tanár) rávilágított arra, hogy a tanítást néhány esetben az ötvonalas tábla hiánya is megnehezíti. 
„Habár alsó tagozaton interaktív tábla van a tantermekben, az énekórai tevékenységekhez mindent a tanító szerez be, például az ütős-ritmus hangszereket." (49 éves nevelőtanár)

„Az internetet a tanárok szerelik, ők hozzák a routert, hogy müködjön az internet a zenehallgatáshoz. Emellett 5 éve rossz a digitális tábla, míg a termekben ötvonalas tábla sincs, amely elengedhetetlen lenne a zenei alapismeretek, például a hangközök vagy a ritmus elsajátításához. Valójában sok mindent a tanárok csinálnak meg vagy szereznek be az énekórai tevékenységekhez." (53 éves ének-zene tanár)

Az eredmények szintén kimutatták, hogy a zenetagozatos iskolák rendelkeznek az énekkari foglalkozásokhoz szükséges kottatárral, azonban az énekszaktanterem kialakítása már nem minden zenetagozatos iskolában megoldott, míg a zenetagozattal nem rendelkező többségi iskolákban szinte egyáltalán nem található szaktanterem.

A tantermek kihasználtságának korlátai elsősorban az általános iskolai 1-2. évfolyamokon mutatkozott meg az énekes játékok és mozgással kísért énekes-zenei tevékenységek végzését illetően: a megkérdezett nevelőtanárok a mozgáshoz szükséges hely hiányát emelték ki. A tanári visszajelzések alacsony mértékben érintették az énekórai tevékenységek zenei tabletekkel történő kiegészítését. Sőt, az interjúk során volt olyan zenetagozatos iskolában tevékenykedő ének-zene tanár, aki erőteljesen ellenezte a zenei tabletek használatát az énekórán kétségbe vonva azok gyakorlati hasznát és eredményességét az iskolai zeneoktatásban.

Mindemellett az ének-zene tanítással kapcsolatos mindennapos problémák között 2 tanár említette a szabad tankönyvválasztás hiányát, amely alapvetően megnehezíti mind a tanítás, mind a tanulás eredményességét. Ugyanakkor az eredmények azt mutatták, hogy a megkérdezett tanárok többsége kevésbé használ tankönyveket az énekórán, a tankönyvhasználat elsősorban az általános iskola alsó tagozatos évfolyamain jellemzőek.

„Nincs tankönyv, helyette használt tankönyv vándorol évről évre, a mostanival pedig nem vagyok elégedett, de mivel nincs szabad tankönyvválasztás, abból kell dolgoznom, ami rendelkezésre áll." (53 éves nevelőtanár)

„Nincs akkreditált 8. évfolyamos tankönyv, az iskola döntése miatt csak egy bizonyos tankönyvet használhatunk, ami tele van hibákkal." (53 éves ének-zene tanár)

\section{A zenei tananyaggal kapcsolatos tanári nézetek}

A kutatást megelőzően kiemelt szerepet tulajdonítottunk a zenei tananyag részletesebb vizsgálatának. Ahhoz, hogy biztosítsuk a vizsgálati eredmények megbízhatóságát, a tananyaggal kapcsolatos témakört több tényező mentén 
közelítettük meg: a tananyag tanulhatósága, nélkülözhetetlen része és hasznossága szempontjából, melyet a tanárok módosítási javaslatainak összegyüjtésével és a könnyüzene tanításáról alkotott nézeteik bemutatásával zártunk.

\section{A zenei tananyag tanulhatósága}

Az interjú további részében a következő kérdést intéztük a tanárokhoz: „Van-e olyan része a tananyagnak, amely nem mindenki számára megtanulható?" A 15 tanár közül 4 pedagógus (1 nevelőtanár, 2 zenetagozatos és 1 nem zenetagozatos osztályban tanító ének-zene tanár) vélte úgy, hogy a zenei tananyag minden egyes része megtanulható a tanulók számára. Azok a tanárok, akik megkérdőjelezték a zenei tananyag minden tanuló számára való megtanulhatóságát, 6 tanár a kottaolvasás és a szolmizáció elsajátítását, 5 pedagógus az egyéb zenei képességeket és készségeket igénylő zenei tevékenységek, mint például az éneklés elsajátításának nehézségeit, míg 3 tanár a 8. évfolyamos tankönyv 20. századi zenei részét nevezték meg.

„A kottaolvasás egy külön nyelv, egyben lehetőség is. Jó lenne, ha mindenki ismerné felnőttként is. Sajnálatos módon nem mindenki tanulja meg alsó tagozaton, de elindul egy folyamat." (53 éves nevelőtanár)

„A képességmozzanat számonkérése számos problémát vet fel azok körében, akiknek botfüle van és/vagy nem rendelkezik szép hanggal. Ennek ellenére folyamatosan bátorítom a tanulókat, hogy énekeljenek egyedül: „énekelj, nem baj, ha csúnya". Úgy érzem, hogy biztosan fejtünk ki hatást, még ha nem is látványos." (60 éves, gimnáziumi ének-zene tanár)

„Úgy vélem, hogy a 8. évfolyamon a 20. századi rész, például Psalmus Hungaricus, illetve a Bartók-művek tanulása nehéz és sok esetben emészthetetlen a tanulók számára. Egyszerüen biológiai szempontból éretlenek még ezekhez a zenékhez a gyerekek, túl nehéz számukra." (47 éves, általános iskolai ének-zene tanár)

Az eredmények alátámasztották, hogy a tanulók tudásbeli különbségei már az alsó tagozaton megjelennek. Ennek következtében a diákok (különösen a nem zenei osztályokban) számos esetben hiányos zenei ismeretekkel kezdik meg tanulmányaikat az általános iskola felső tagozaton. Tehát a zenei képességfejlesztés már ebben az iskolaszakaszban komoly nehézségekbe ütközik, amely a gimnáziumban szinte visszafordíthatatlanná válik.

\section{A tananyag nélkülözhetetlen része}

A megkérdezett tanárok közül 2 pedagógus (1 nevelőtanár, 1 nem tagozatos ének-zene tanár) nyilatkozott úgy, hogy a zenei tananyag minden része fontos. Mindemellett az interjúk során a kottaolvasás, avagy a zenei írás-olvasás 
elsajátításának fontosságát mintegy 9 pedagógus emelte ki, míg az éneklés megszerettetését 6 ének-zene tanár vélte nélkülözhetetlennek. Az eredményeket a 2. táblázatban szemléltetjük.

„A zenei alapismeretek (például a zenei írás-olvasás, hangközök, ritmus) elsajátítása, minimális zenetörténeti háttérrel." (35 éves, zenetagozatos iskolában tanító ének-zene tanár)

„Úgy vélem, a zenei tananyag minden része fontos és elengedhetetlen. Első félévben mindig dalokkal kezdünk és készségfejlesztéssel, majd a második félévben - miközben még mindig jelen vannak a népdalok - az órákba belecsempészem a zenetörténetet, a klasszikus zeneműveket, valamint a szolmizálást." (53 éves, nem tagozatos iskolában tanító ének-zene tanár)

„Tekintettel a tanulók hiányos zenei ismereteire a többszólamban történő éneklés megkönnyítése érdekében nélkülözhetetlennek találom az énekelhető énekes anyagok biztosítását. Mindemellett fontosnak találom a kézjelek, a hangnemek, abc-s hangok, a ritmusképletek, valamint a szolmizációs hangok neveinek elsajátítását és megszólaltatását." (55 éves gimnáziumi ének-zene tanár)

„A nem zenetagozatos osztályokban kottaolvasás helyett inkább kottaismeretről beszélnék; az elsődleges cél az, hogy a tanulók el tudjanak igazodni a kottában, ismerjék a jelrendszert, valamint az időbeliségét és térbeliségét a zenének. Emellett ugyancsak fontosnak találom a zenetörténeti ismeretek megszerzését, amely egyfajta világképet ad a tanulók számára. A népzenét sok esetben összekötjük mozgással, hangszeres és ritmusgyakorlatokkal, amelyeket - úgy érzékelem - nagyon élveznek a tanulók, mindeközben közösen énekelnek." (60 éves gimnáziumi ének-zene tanár)

A kottaolvasás tekintetében némely tanár megjegyezte, hogy a zenei alapismeretek megalapozása ellenére sok gyermek nem tudja kellőképpen elsajátítani a szolmizálást, melyet az időkerettel és a szolmizáció nehézségével indokoltak. Az eredmények arra mutatnak rá, hogy a tanulók kottaolvasási ismereteinek és készségeinek elsajátítása már az általános iskolában háttérbe szorul. Ugyanakkor a zenei írás-olvasás elsajátításával kapcsolatos tanári nézetek között néhány esetben ellentmondást tapasztaltunk az interjúk során. Az eredmények arra mutatnak rá, hogy mélyebb zenei alapismereteket elsősorban a zenetagozatos osztályokba járó tanulók szereznek, ugyanakkor azokban az osztályokban is némely tanár csak érintőlegesen koncentrál a relatív szolmizációval történő kottaolvasásra. 
„A szolmizációt a normál osztályokba járó tanulóknak nem is igen tanítom, mert egyszerüen heti 1 órában képtelenség megtanulni szolmizálni, soha senki nem tudott, és nem is fog tudni. Helyette azokban az osztályokban a zenei ízlésformálásra és az éneklés megszerettetésére koncentrálok. A zenetagozaton már másabb a helyzet, a kórusmüvek megtanulásához már hasznos eszközzé tud válni a szolmizáció." (30 éves ének-zene tanár)

A kottaolvasás, tiszta intonáció, szolmizáció, valamint a műmemória (köztük Palestrina, Bach és Mozart zeneművei) elengedhetetlen. Azonban ha nincs elég óraszám, a tanár nem tudja megvalósítani." (50 éves zenetagozatos általános iskolában tanító ének-zene tanár)

„Úgy vélem, a műveltség és az élmény fontosabb, mint a szolfézs-zeneelmélet, amit csak érintőlegesen tanulnak a gyerekek, míg a szolmizálás csak eszközként jelenik meg a kóruspróbákon.” (47 éves zenetagozatos általános iskolában tevékenykedő ének-zene tanár)

Az eredmények rámutatnak arra, hogy némely tanár az élményszerzésnek nagyobb prioritást adott a szolfézs-zeneelméleti ismeretek szerzésének fontosságával szemben. Egyik nevelőtanár az alapismeretek közül elsősorban a ritmus fejlesztését tartotta fontosnak, míg a zenei (dallam-) hallást veleszületett adottságnak vélte, ebből kifolyólag annak fejlesztését kevésbé találta a zenei tananyag nélkülözhetetlen részének.

Mindemellett a tananyag nélkülözhetetlen tényezőire vonatkozó kérdésünk ellenére néhány tanár a zenei alapmüveltsége mellett az élmény és a jó énektanár' biztosítását nevezték meg.

„Úgy vélem, a tanulók zenei attitűdjét leginkább a tanár személye határozza meg, ezt követi az iskolai közeg, majd az otthoni környezet." (35 éves zenetagozatos iskolában tanító ének-zene tanár)

„A tanár személye döntő fontosságú: amennyiben a tanár elutasított a tanulók körében, meghalt a tantárgy." (60 éves gimnáziumi ének-zene tanár) 
2. táblázat

A tananyag nélkülözhetetlen részei a tanárok szerint

\begin{tabular}{|l|c|c|c|}
\hline \multicolumn{1}{|c|}{ Említett fejlesztési területek } & $\begin{array}{c}\text { Zenetago- } \\
\text { zat } \\
(\mathbf{N =}\end{array}$ & $\begin{array}{c}\text { Nem ze- } \\
\text { (N) }\end{array}$ & $\begin{array}{c}\text { Összesen } \\
\text { (N) }\end{array}$ \\
\hline Kottaolvasás & 6 & 3 & 9 \\
\hline Hallásfejlesztés (tiszta intonáció) & 4 & 2 & 6 \\
\hline Éneklés & 8 & 5 & 13 \\
\hline Zenetörténet & 3 & 5 & 8 \\
\hline Népdalok, népzenei kultúra, hagyományaink & 5 & 3 & 8 \\
\hline Ritmus & 6 & 5 & 11 \\
\hline Ének-zene kapcsolódása a többi tantárgyhoz & 2 & 3 & 5 \\
\hline
\end{tabular}

\section{Hasznosság kérdése}

A megkérdezett tanárok közül 9 pedagógus vélte hasznosnak a zenei tananyag minden egyes részét, míg 2 tanár vonta kétségbe a szolfézs tanulásának hasznosságát, helyette az éneklésnek és a zenei élményeknek adtak nagyobb prioritást. További 3 tanár a korábban említett 8. évfolyamos tankönyv és a gimnáziumi zenei tananyag 20. századi zenei részére vonatkozó tartalmait találták kevésbé hasznosnak a tanulók számára. Ugyanakkor közülük valamennyien jelezték, hogy az adott zenei rész helyett teljesen mást tanítanak az órákon, nagyobb figyelmet fordítva a legpopulárisabb klasszikus zenei szemelvények ismertetésére.

„A szolfézs bonyolultabb, mint ami a tantervben benne van. Ugyanakkor nem mindenkinek hasznos, de mindenkinek meg kell tanulni." (49 éves nevelőtanár)

„Az alfa akkordok megtanítása teljes mértékben szükségtelen, mint ahogyan a kortárs és a későromantikus zenék is. Helyette minél több Palestrina, Bach- és Mozart-művekre lenne szükség." (50 éves zenetagozatos általános iskolai ének-zene tanár)

„A zenei írás-olvasás rendkívül hasznos. Ehhez hasonlóan a tankönyvben leírtak minden része is szintén hasznos. Ugyanakkor a csoportprioritás fontos szerepet kap az órák megszervezése során, amikor elkezd a tanár szelektálni mit lehet és mit nem lehet egy-egy osztályban megvalósítani. Ebből 
kifolyólag vannak kihagyások." (46 éves zenetagozattal nem rendelkező gimnáziumi ének-zene tanár)

A zenetagozatos osztályokban némely tanár a zenei tananyag számos részét kevésbé találta korszerünek, melyeket más zenei tartalmakkal töltenének fel. Ezzel szemben néhány nem tagozatos osztályban tanító énektanár a tanulói visszajelzéseket érintették a zenetanulás hasznosságára vonatkozóan. A tanári visszajelzések alapján némely tanuló (különösen a nem zenetagozatos osztályokban) kevésbé tekinti hasznosnak az iskolai zenetanulást, s látja annak a felnőttkorban történő hasznát. A tanárok a tananyag módosítására vonatkozó javaslatait a tanulmány következő részében mutatjuk be.

„Az órákon néhány gyermek néha megkérdőjelezi például a hangközök tanulását, mikor fogják ezt használni felnőttkorukban. Ettől függetlenül a tanár megtanítja. (35 éves általános iskolai ének-zene tanár)

„A gyerekek szokták mondani: az éneklés fontos lesz a munkahelyen?” (47 éves általános iskolai ének-zene tanár)

\section{A tananyag módositására irányuló tanári nézetek és javaslatok}

Korábbi feltételezésünk során abból indultunk ki, hogy a tanárok többsége célszerűnek találja a zenei tananyag modernizálását. Az eredmények alátámasztják hipotézisünket; a megkérdezett 15 ének-zene tárgyat tanító tanár közül 3 pedagógus ( 1 nevelőnő és 2 gimnáziumi ének-zene tanár) jelezte, hogy nem módosítana a zenei tananyagon, míg a többi ének-zene tanár különböző javaslatokat fogalmazott meg a zenei tananyag megújítására vonatkozóan.

A megkérdezett 3 nevelőtanár közül 2 tanár jelezte a zenei tananyag módosításának szükségességét; az egyik a közösségépítő dalok növelését szorgalmazná a népdalok rovására a dalanyag bővítése és változatossága érdekében, míg a másik nevelőtanár a szabad tankönyvválasztás lehetőségének hiányát kifogásolta. Ezzel szemben a jelenlegi tananyaggal elégedett harmadik nevelőtanár szerint az általános iskola 1-2. évfolyamán kielégítő az ének-zene tananyaga, illetve a Mozaik Kiadó rendelkezésre álló ének-zene tankönyvét is megfelelőnek találta.

Ezzel szemben a felső tagozaton tanító ének-zene tanárok többsége elégedetlenségét és nemtetszését fejezte ki a tananyaggal kapcsolatosan, ugyanakkor néhány esetben egymással ellentétes javaslatokat fogalmaztak meg. Két zenetagozatos iskolában tanító énektanár a komolyabb hangvételü zenemüvek irányába nyitna szívesebben, míg 3 tagozatos iskolában tanító pedagógus a könnyedebb stílusú kompozíciók tanítását találta szükségszerünek.

„Úgy vélem, hogy nem korszerüek és nem izgalmasak a zenei példák a tagozatos könyvekben, emiatt a tankönyvekben módosítani kellene a zenei 
anyagot. Ha megnézzük a mai 6. évfolyamos fiúkat, nem hinném, hogy Beethoven Mormotás fiú dalát szívesen éneklik. Helyette sokkal inkább egy érettebb, gyermekközpontú anyagra lenne szükség, amely például tartalmaz romantikus operát, míg egy „Mormotás fiú dala” sok esetben nevetség tárgyát képezheti a mai kamaszok körében." (35 éves zenetagozatos iskolában tanító ének-zene tanár)

„Az alfa akkordok tanulása teljesen értelmetlen, mint ahogyan se kortárs, se későromantika ne legyen a tananyagban. Helyette nagyon fontosnak találom, hogy kellő idő jusson Palestrina, Bach és Mozart műveire." (50 éves zenetagozatos iskolában tevékenykedő ének-zene tanár)

„A 8. évfolyam 20. századi zene tananyagán módosítanék. Az alacsonyabb évfolyamokon a balladák, Kodály Háryja vagy például a népdalok közül A Vidrócki híres nyája tanulása iránt érdeklődtek a tanulók, de a 20. századi zenei anyagot nem tudják befogadni, éretlenek hozzá." (47 éves zene- és nem zenetagozatos iskolában tevékenykedő ének-zene tanár)

„Mindenképpen módosítani kellene a 8. évfolyam tananyagán. Bartók Cantata Profana túl nehéz a gyermekek számára. Úgy látom, hogy a gyerekek nincsenek ilyen szinten érettségben. Helyette inkább slágergyanús müvek kellenének, mint például Allegro barbaro vagy Este a székelyeknél, míg a 7. évfolyamos betlehemes játékok helyett szép adventi énekekkel lehetne feltölteni a zenei tananyagot." (35 éves zene és nem zenetagozatos iskolában tevékenykedő ének-zene tanár)

„Az egész 8. évfolyamos tankönyvet le kellene cserélni (például Bartók hangszeres szemelvényekre nincs szükség), ugyanígy a 7. évfolyamos anyagon is lenne mit módosítani könnyedebb irányba. Sok zenéhez még nem érettek a tanulók. Helyette nehezebb Schumann- és Schubert-dalokat kellene tanítani. Ugyanakkor nagyon fontosnak találom, hogy a zenei anyagot-tankönyvet kizárólag 40 év alatti korosztály írja meg." (30 éves zene és nem zenetagozatos iskolában tevékenykedő ének-zene tanár)

A gimnáziumi zeneoktatás tekintetében 6 ének-zene tanár közül 4 pedagógus az elméleti ismeretekre szánna kevesebb időt, s helyette az aktív zenei tevékenységeket részesítené előnyben az énekórák folyamán.

„A zenetörténeti-elméleti részt sürgősen süríteni kellene, s helyette fontos, hogy az ének-zene tantárgy sokkal inkább egy aktív zenei tevékenység legyen. Az éneklés játékosan történjen, ritmustapsolással és mozgással kiegészítve. Mindehhez kapcsoljuk hozzá az alapmüveltséghez szükséges szolfézs és zenetörténeti ismereteket." (60 éves zene- és nem zenetagozatos gimnáziumban tevékenykedő ének-zene tanár) 
„A zenetörténeti részből vennék el, leszűkíteném az elméletre fordított időintervallumot, például az oratórium tanulására szánt időt. Sok, többféle zenei példa és zenehallgatási anyag segítségével haladnánk. Helyette az énekes anyagra szánnék több időt, elsősorban kétszólamú zeneművek, mint például a Kodály bicíniumok irányába strukturálnám át a zenei tananyagot, amelyeket 2 óra alatt meg lehetne tanulni." (55 éves gimnáziumi ének-zene tanár)

„Ha követném a tananyagot, az órán össze-vissza kapkodnánk. Mindig lehetne szúkíteni a tananyagon, például a dodekafónia egyáltalán nem szükséges, még a zenészek sem használják, csak egy szűk köre. Mint ahogyan a későromantika, Honegger vagy Sosztakovics sem szükséges, míg Carl Orff tanulásánál csak a Carmina Buranát tartom fontosnak néhány zenei részlettel füszerezve. Ugyanakkor az ének-zene tanítás során fontosnak találom a fontossági sorrend felállítását, azaz fontosabb az élményközpontú tanítás, mint a követelményrendszer. A gimnáziumi oktatásban inkább érdekességeket tanítanak a tanárok. A cél az, hogy a tanulók élvezzék az énekórákat. Ebből kifolyólag a legpopulárisabb komolyzenéket választja a tanár; kevesebb zenét, de több érdekesebb részlettel, azaz inkább egy zeneszerzőt több órán keresztül." (43 éves gimnáziumi ének-zene tanár)

„Ezt a tananyagot akkor találták ki, amikor heti 2 énekóra volt. A jelenlegi oktatásban, heti egy énekórával nem lehet minden témában elmélyedni." (52 éves gimnáziumi ének-zene tanár)

Mindemellett másik két gimnáziumi ének-zene tanár (egy tagozatos és egy nem zenetagozatos iskolában tanító pedagógus) a rugalmasság fontosságára hívták fel a figyelmet, rávilágítva az előírt zenei tananyag iránymutató szerepére, amely során a tanár a tanulók képességeinek és előzetes zenei ismereteinek felmérést követően határozza meg és tervezi meg az énekórák anyagát és tevékenységeit. A tanulmány következő részében egy 46 éves gimnáziumi énektanárral készített interjú részleteit közöljük.

K: Módosítana-e a zenei tananyagon?

T: Ez nekem egy keret. Az ember fejében van egy csoportprofil az adott osztályról, van egy elképzelésed a csoportról, a tanulók képességeiről és zenei tudásáról. S ha van kellő tapasztalata az énektanárnak, akkor tudja, hogy az adott csoportprofilra hogyan tudja a keretet alkalmazni. Nyilvánvalóan az a célunk, hogy egy kicsit mindig magasabbra tegyük a lécet. Amikor a tankönyvben elrugaszkodott dolgokat látunk, akkor azt nem annak kell kezelni, hanem egyszerüen a tankönyvíró a nagyon profi csapatokra is gondol. A müvészeti tárgyaknál ez megengedhető, ez nem olyan, mint egy matekóra. 
K: Van-e olyan része a tananyagnak, amit kihagy?

T: Van, persze. Például a 20. századi irányzatokra nem nagyon van idő, olyankor a 20. századi irányzatok mélyreható vizsgálata helyett inkább behatóbban tanulmányozzuk Kodályt. Ilyenkor van az, hogy az ember mérlegel és megkérdezi önmagától, hogy akkor mi a fontosabb vagy mi visz közelebb a célhoz

K: S mi a helyzet a zenei írás-olvasás elsajátításával és gyakorlásával?

T: Öszintén szólva én azt is kihagyom, mert az is egy olyan történet, aminek ha nincs egy előzetes megalapozottsága, akkor megint azt fogod elérni, hogy a tanulónak semmilyen sikerélménye nem lesz, nemhogy zenei élménye. Az én gimnáziumomban a gyerekek sok esetben olyan környezetből érkeznek, ahol sok esetben esélyük sem lehetett volna, hogy rendesen megtanuljanak szolmizálni vagy, hogy megtanuljanak kottázni... Ennek következtében nem igazán látom értelmét annak, hogy kezdjem el erőltetni azt, ami helyett olyat tudok tanítani, amit élvezni fog a gyermek, s ami még mindig érték lesz számára. Tehát nyilván nem önkényesen hagyok ki bizonyos dolgokat, hanem egészen egyszerüen felmérem az adott csoportnak a készségszintjét, amiről folyamatosan azt látom, hogy nincs megalapozva. Ez nem jó megoldás...ugyanakkor az adott helyzetben ez a legkevésbé rossz megoldás.

A tananyag tanulhatósága szempontjából korábban rávilágítottunk, hogy számos tanár kevésbé tartja befogadhatónak a zenei írás-olvasás elsajátítását a tanulók számára. Míg az imént bemutatott gimnáziumi ének-zene tanár nyilatkozatából kiderül, hogy a gimnáziumi zeneoktatás során sok esetben nehézséget jelent a tanulók legalapvetőbb zenei ismeretekre kiterjedő zenei előképzettségének hiánya, ezt a tudást az általános iskola elején kellett volna elsajátítaniuk a tanulóknak. Mindeközben a hiányosságok pótlására - a nem zenetagozatos általános és gimnáziumi osztályokban - nem áll rendelkezésre kellő idő az új tananyag leadása, valamint az aktív zenei tevékenységek, például az éneklés együttes biztosítása mellett. Az eredményekből arra következtethetünk, hogy a diákok zenei tudásának hiányosságai alapvetően befolyásolják a tanár tananyaghoz való alkalmazkodását, valamint az énekórák megtervezését, amely számos esetben a tananyag bizonyos részeinek elhagyásához vezet.

\section{A könnyüzene tanitása az iskolai énekórákon}

Az interjúk folyamán arra voltunk kíváncsiak, hogy a megkérdezett énektanárok hogyan vélekednek a könnyüzene iskolai keretek között történő tanításáról. A kutatást megelőzően feltételeztük, hogy a tanárok ellenzik a könnyűzene iskolai tanítását. Az eredmények elemzése során hipotézisünk begazolódott. Jóllehet a 8 . évfolyamos tananyag már tartalmaz könnyűzenei részleteket, ennek ellenére a megkérdezett tanárok többsége nemtetszését 
fejezte ki az iskolai könnyüzenei oktatásra vonatkozóan, helyette a zenei ízlésformálást és az értékes zenére való nevelést tartották fontosnak.

Ugyanakkor némely tanár jelezte, hogy kizárólag ismerkedés szintjén a félév és/vagy a tanév utolsó óráin foglalkoznak könnyüzenével az énekórán. Ugyanakkor a zenetagozatos osztályokban előfordult, hogy éppen egy kórusfesztiválon való szereplés igényelte a könnyedebb stílusú darabok tanulását. A tanárok a könnyűzene iskolai tanítása ellen szóló érvei a könnyüzenei szakemberek hiányát, az ének-zene órák eleve alacsony óraszámát, a tanulók tanárokkal szembeni esetleges magasabb könnyüzenei műveltségét, valamint az iskola hagyományőrző szerepének csorbulását érintették.

„Nem kellene tanítani, helyette inkább megfigyelési szempontokat lenne érdemes adni, hogy a gyermek önálló döntést hozzon. Fontos lenne, hogy tudatosan megismerjék, hogy mi az értékes." (49 éves nevelőtanár)

„Támogatom, hogy virtuózokat nézzen a gyermek, de a könnyüzene oktatását nem hoznám be. Helyette sokkal inkább az igényes zene (klasszikus zene) megtanítása a cél, amivel a tanulók nem találkoznak iskolán kívül.” (53 éves nevelótanár)

„Az értékes könnyűzene belefér, amely a tanulók ízlését jó irányba formálja. Ritkán előfordul, hogy mutatok néhány könnyüzenét példaként, hogy a gyermekek tudják, hogy mi az értékes. Ugyanakkor olykor a kórusművészet is megkívánja a könnyűzenét, amelynek hatására el kell menni a populárisabb müfajok felé, gondolok itt a kortárs zenére vagy a filmzenékre." (35 éves zenetagozatos iskolában tanító ének-zene tanár)

„Minek bevinni?! Egyáltalán nem értek vele egyet. Az énekórákon rendkívül ritkán említem meg, hogy a könnyüzene honnan lopja a zenéket. Ettől függetlenül úgy vélem, hogy nem a könnyedebb ellenállás felé kell menni, ne válasszuk a könnyebbik utat. Aki megmászta a hegyet, csak az tudja megmondani milyen az út." (50 éves zenetagozatos iskolában tanító ének-zene tanár)

„A tanulók néha kérdezik, hogy miért nem hallgatnak olyan zenét, amit ők szeretnek. De én úgy vélem, hogy az iskola feladata más, könnyüzenét bárhol hallgat a gyermek. Biztosan nem lenne jó, ha felváltaná a népzenét a könnyüzene." (35 éves zene és nem zenetagozatos iskolában tanító ének-zene tanár)

„Nem tanítom. Ugyanakkor úgy vélem, hogy a komolyra sincs idő, de nem is értek hozzá, ugyanakkor nem is hiányzik." (53 éves,nem zenetagozatos iskolában tanító ének-zene tanár)

„Nem vagyok biztos abban, hogy okosabbak vagyunk, mint ők!” (60 éves gimnáziumi ének-zene tanár) 
„Nincs hozzá szakember. Néha tanítok könnyűzenét; évente háromszornégyszer. Előfordult, hogy fellépésekre olyan anyagra volt szükség." (30 éves zene- és nem zenetagozatos iskolában tanító ének-zene tanár)

„Nem kell nagyon nagy teret adni neki. Egy-egy karácsonyi órán ritka alkalommal előfordul, de akkor is csak az igényes zenék, mint például Pentatonix vagy King’s Singers." (43 éves gimnáziumi ének-zene tanár)

„Nagyon ritkán be lehet vinni az órákba, de csak ismerkedés szintjéig, elemezni nem kell. Ugyanakkor úgy vélem nem érdemes elzárkózni, különben az a te hiteltelenségedet és műveletlenségedet kelti." (46 éves gimnáziumi tanár)

„A gyerekek legtöbbször azt gondolják, hogy annak a zenének kellene lennie a zenei tananyagnak, amit ők hétköznaponként hallgatnak. Egyébként én próbálkoztam is már régebben ilyesmivel... Úgy döntöttem, hogy akkor dolgozzunk a tanulók által hozott anyagból, de azt vettem észre, hogy a 'mutasd meg a kedvenc együttesedet vagy a kedvenc számodat' kezdetű kezdeményezések gyakorlatilag ugyanolyan érdektelenségbe fulladtak néhány perc után, mintha a hivatalos tananyagot követtük volna az adott órán. Nyilvánvalóvá vált számomra, hogy a tanulókat az általuk jobbnak vélt tananyag sem érdekli, már csak azért sem, mert nagyon különböző a zenei érdeklődésük is." (52 éves gimnáziumi ének-zene tanár)

\section{Tanári javaslatok az iskolai zenei nevelés javitására vonatkozóan}

Az interjúk során számos énektanár megfogalmazott javaslatokat az iskolai ének-zene oktatás eredményességére és fellendítésére vonatkozóan. Az észrevételek említésekor a tanárok kiemelt figyelmet fordítottak az ének-zene tantárgy alacsony óraszámára és az ének-zeneoktatás mindennapos problémáira. A tanárok által említett javaslatokat témakörök szerint csoportosítottuk, valamennyi témát egy-egy tanár nyilatkozatával szemléltetjük.

\section{Az énektanár személye}

Némely tanár úgy vélte, hogy az ének-zene oktatás minősége és presztízse alapvetően a megfelelő tanárok munkájával biztosítható. Ugyanakkor a tanulók zenei előképzettségének, zenei tudásának hiányosságai szintén a megfelelö ének-zene szakos tanárok foglalkoztatásával csökkenthetők.

„A tanulók már az általános iskolai alsó tagozatán hiányos zenei tudással kerülnek hozzám. Annak érdekében, hogy csökkentsük a tanulók tudásbeli hiányosságait, nélkülözhetetlen, hogy ének-zene szakos tanár tanítsa az énekzenét általános iskola 1. osztályától kezdve." (53 éves ének-zene tanár)

\section{Az ének-zene tantárgy óraszáma}

A jó énektanárok alkalmazása mellett hasonlóan fontos az ének-zene tantárgy minimum óraszámának biztosítása is. Egy speciális Kodály iskolában 
tanító zenetanár a következőképpen festette le az ének-zene tantárgy helyzetének javításához szükséges óraszámok eloszlását.

„A jó zeneoktatáshoz nem zenei tabletek kellenek. Az ének-zene oktatás helyreállítása két tényezőtől függ: megfelelő óraszám és tanárok biztosítása. Számok tekintetében 1-4. osztályban heti 4 óra lenne szükséges a zenei alapismeretek és a szolmizáció elsajátításához és megszilárdításához. Ezt követően felső tagozaton a zenetagozatos osztályokban heti 4 órát, míg a nem zenetagozatos osztályokban heti 2 órát kellene biztosítani az ének-zene óraszámának." (50 éves ének-zene tanár)

\section{Az osztályozás problematikája}

A tanulók alacsony zenei önbecsülésének javítására egy gimnáziumi tanárnő az ének-zenéből történő számonkérés és osztályozás eltörlését kezdeményezte.

„Úgy vélem, nem lenne szabad osztályozni az ének-zenét, alapvetően sok negatív attitüdöt szül. Aki nem olyan tehetséges, nincs jó hallása és/vagy nem rendelkezik szép hanggal sok esetben kudarcként éli meg az énekórákat. Ugyanakkor az ének-zene presztízsét tekintve úgy vélem, hogy amennyiben az ének-zene pontot érne a továbbtanulás során, minden bizonnyal többen megbecsülnék." (60 éves gimnáziumi ének-zene tanár)

\section{A zenei tananyag modernizálásának szüksége}

A tananyagra vonatkozó módosítások a tankönyvírók személyét és a tananyag modernizálását egyaránt érintették. Mindemellett néhány tanár a szabad tankönyvválasztás hiányát kifogásolta, amely kapcsán a tanároknak számos esetben „meg van kötve a kezük” - nyilatkozta egy 53 éves általános iskolai ének-zene tanár. A legtöbb tanári egyetértés a 8. évfolyamos tankönyvvel kapcsolatosan született, miszerint a tanárok többsége szükségesnek találta a 20. századi zenei szemelvények tanításának elhagyását. Hasonló visszajelzések érkeztek a gimnáziumi oktatás 20 . századi zenei irányzatok tanulását illetően.

„Részben a tanár és diák közötti generációs problémák kiküszöbölése, valamint a zenei tananyag radikálisabb modernizálása kapcsán kiemelten fontosnak találom, hogy a tankönyveket kizárólag 40 év alatti korosztály írja meg."

\section{Alacsony óraszám és a tananyag aránytalansága}

Némely tanár az interjúk során felhívta a figyelmet arra, hogy a jelenlegi tananyagok heti 2 órára terveződtek, amelyre a gyakorlatban heti egy óra áll rendelkezésre, melynek következtében alapvetően nem várható el a zenei tananyag teljes átadása a tanulók számára az énekórákon. Ennek hatására a tanárok többsége nagyobb prioritást adott az éneklésnek és a zenehallgatási tevékenységnek az elméleti részekkel szemben. Tekintettel arra, hogy az aktív zenei tevékenységek a zenei élményt szolgálják, a megkérdezett pedagógusok az elmélet átadására kevesebb időt szánnának. 
„Az órák 70\%-a énekléssel és mindössze 30\%-a teljen elmélettel. A zenei tananyagot is eszerint kellene összeállítani." (35 éves zenetagozatos iskolában tanító ének-zene tanár)

\section{Fontossági sorrend felállítása}

Tekintettel az alacsony óraszámra, a tanulók különböző zenei képességi szintjére és adottságára némely tanár (különösen a gimnáziumi oktatásban) a csoportprioritást, a tanulók képességéhez való alkalmazkodást és tervezést hangsúlyozta.

\section{Számonkérés és szigorúság ének-zene tantárgyból}

A vizsgálat további részében arra kerestük választ, hogy egy folyamatosan háttérbe szoruló készségtantárgy esetén az adott tantárgyat oktató tanárok miként ítélik meg a követelményrendszer és a számonkérés mélységét és szigorúságát. Az interjúalanyokhoz a következő kérdést intéztük: „Van-e olyan része a zenei tananyagnak, amelynek nem teljesítése esetén fennáll a buktatás lehetősége?" Előzetes várakozásunkban a nem zenetagozatos osztályokban mérsékelt-elnéző szigorúságú számonkérését, míg a speciális zene tagozatos osztályokban a zenei alapismeretek szigorúbb tanári értékelését feltételeztük. A válaszadóktól kapott válaszokat a tagozat alapján különítettük el. Az eredmények alapján három kategória körvonalazódott ki:

(1) Szigorú-elvű: Az ének-zenéből való buktatás megengedett; korábban történt buktatás, a jelenlegi gyakorlatban olykor előfordul,

(2) Mérsékelt-elvü: Az ének-zenéből való buktatás elvileg lehetséges. Történt már buktatás az iskolában, de nem bevett szokás, ugyanakkor elégtelenelégséges érdemjegy előfordul.

(3) Engedékeny-elvü: Az ének-zenéből való buktatás elvileg lehetséges, de egyáltalán nem gyakorlat. Korábban nem történt buktatás, valamint az elégtelen-elégséges érdemjegy sem jellemző a számonkérés és osztályozás során. Az eredményeket a 3. táblázatban foglaljuk össze.

3. táblázat

A tanároknak az ének-zenéböl történő számonkérés szigorúságáról alkotott nézete

\begin{tabular}{|l|l|l|l|}
\hline \multicolumn{1}{|c|}{$\begin{array}{c}\text { A számonkérés } \\
\text { szigorúságának mértéke }\end{array}$} & $\begin{array}{c}\text { Ének-zene } \\
\text { tagozat } \\
(\mathbf{N})\end{array}$ & $\begin{array}{c}\text { Nem zeneta- } \\
\text { gozat } \\
(\mathbf{N})\end{array}$ & $\begin{array}{c}\text { Összesen } \\
(\mathbf{N})\end{array}$ \\
\hline Szigorú-elvü & 2 & 1 & 3 \\
\hline Mérsékelt-elvü & 3 & 4 & 7 \\
\hline Engedékeny-elvü & 1 & 4 & 5 \\
\hline
\end{tabular}


Az eredmények azt mutatták, hogy az ének-zenéből történő számonkérés szigorúsága tagozatok tekintetében eltérő, ugyanakkor az adott tanár személye is erőteljesen meghatározza. Az általános iskolai zeneoktatás tekintetében az ének-zene tagozatos osztályokban tanító 6 pedagógus közül 4 tanár számolt be ének-zenéből történő buktatásról, közülük két tanár a szigorúelvű számonkérést támogatta, míg a nem zenetagozatos osztályokban tanító tanárok közül mindössze egy pedagógus jelezte, hogy korábban történt buktatás ének-zenéből az iskolájában. A többi nem tagozaton tanító tanár ellenezte az énekből történő buktatást, ugyanakkor fenntartották a rosszabb érdemjegy szerzésének lehetőségét a tanulók felkészülésének hiánya és zenetanulás iránti teljes érdektelensége esetén. Összességében az eredményekből arra következtethetünk, hogy az énekből történő buktatás korántsem bevett szokás, azonban a zenetagozaton nagyobb valószínüséggel szigorúbban megkövetelik a tanárok az adott tananyag visszaadását a tanultól, mint a nem tagozatos osztályokban.

„Úgy vélem, a tantárgy van a gyerekért, nem a gyermek a tantárgyért. Hármas érdemjegynél rosszabbat sosem adok. A tanár feladata az, hogy fejlessze a gyermekeket, valamint, hogy becsalogassa őket." (53 éves nevelötanár)

„Néha buknak énekből, ha valaki teljes mértékben ellenáll, például nem tanul dalt, sem ritmust vagy kottázást." (53 éves nem tagozatos általános iskolai ének-zene tanár)

„Szoktak bukni énekből, amikor a szándék tökéletes hiányát tapasztalom. A tagozaton olykor elő szokott fordulni, a normál osztályokban viszont nincs ilyen. (35 éves zene- és nem zenetagozatos általános iskolában tanító énekzene tanár)

„Van egy minimum, emiatt rossz jegyet szoktam adni, de buktatni nem." (47 éves, zene és nem zenetagozatos iskolában tanító ének-zene tanár)

Egyszer történt buktatás énekből, amelyet a tanuló teljes mértékủ ellenállása és az órák állandó akadályozása előzött meg. Végül sikerült a tanulónak a pótvizsga." (55 éves zene- és nem zenetagozatos gimnáziumban tanító énekzene tanár)

„Lehet buktatni énekből, de szégyen mind a tanulónak, mind a tanárnak. Ha nincs felkészülés a tanuló részéről, szoktam adni elégtelen osztályzatot, de soha sem buktatok. Úgy vélem nem szabad odáig eljutni: ne hozd se magad, se a tanítványt ilyen helyzetbe." (46 éves nem tagozatos gimnáziumi énekzene tanár) 


\section{A számonkérés folyamata és típusa}

Az eredmények azt mutatják, hogy a számonkérés formája és típusa szintén jelentősen eltér a tagozatos és normál osztályok között. Az eredmények azt mutatják, hogy a nem tagozatos osztályokban tanító tanárok többsége engedékenységet tanúsított a szóbeli számonkérés tekintetében, amely során a félénkebb tanulók számára engedélyezve van a csoportosan történő felelés, ugyanakkor az elméleti rész visszaadása esetén már szigorúbban értékelik a tanulók teljesítményét.

Ezzel szemben a zenetagozatos iskolákban a számonkérés jelentősen szigorúbban történik a nem zenetagozatos osztályokhoz képest. Ugyanakkor az eredmények arra mutatnak rá, hogy a tanár személye erőteljesen meghatározza a követelményrendszer szigorúságát, amely a megkérdezett zenetagozatos osztályokban tanító tanárok körében némely esetben eltérő.

„Nincs megszégyenítés, semmi szigorúság. Aki rosszabb hangú, 2-3 gyermekkel együtt énekel. Az érdeklődés felkeltése a legfontosabb." (49 éves nevelötanár)

„Szoktunk beénekelni. A röpdolgozat csak a tanárnak visszajelzés. A számonkérés énekléssel történik: a félénkek együtt, a bátrak szólóban. A kézjeleket és a szolmizációs hangokat tudni kell, év végén mindig tudáspróbával zárunk." (53 éves nevelőtanár)

„A számonkérés szigorú. Minden darabot felmondatok a gyerekekkel, akik szólóban felelnek (ez nagyon fontos), mivel ezáltal biztonságos tudásra tesznek szert, eközben a stresszhelyzetet is szokták és magabiztosak lesznek. Későbbiekben biztosan hasznos lesz számukra, megtanulják a vizsgahelyzetet. Biztosan így van, folyamatosan kapom a pozitív visszajelzéseket a viszszatérő növendékektől, akik emiatt nagyon hálásak nekem." (35 éves zene- és nem zenetagozatos iskolában tanító ének-zene tanár)

„A számonkéréskor kártyákat készítek, mindegyik egy feladatot tartalmaz. Ahány kérdésre tud választ adni a tanuló, annyit ér a jegy." (43 éves gimnáziumi ének-zene tanár)

\section{A Kodály-módszer alkalmazása az iskolai gyakorlatban}

Annak érdekében, hogy megvizsgáljuk, a megkérdezett tanárok mennyire veszik szigorúan a kodályi alapelvek megvalósítását az iskolai oktatásban, az interjúalanyok számára a következő kérdést intéztük: „Milyen zenepedagógiai módszereket ismer és alkalmaz az ének-zene órák során?” A kutatás során arra voltunk kíváncsiak, hogy az énektanárok milyen pedagógiai ismeretekkel rendelkeznek és módszerekkel tanítanak az énekórák folyamán. Előzetes várakozásunkban feltételeztük, hogy a tanárok a kodályi gondolatok iskolai megvalósítását szem előtt tartva a zenei képességek fejlesztésére és az 
élmények együttes biztosítására törekednek. Azonban az eredményeink azt mutatják, hogy a hipotézisünk csak részben nyert igazolást.

A pedagógusinterjúk során 15 énektanár közül 10 pedagógus nevezett meg zenepedagógiai módszereket; köztük 10 fó a Kodály-módszert, 5 fó az Orffmódszert, 2 fó a Dalcroze-módszert, illetve 1 fó a Kokas-módszert. Azon tanárok közül, akik megnevezték a - Nemzeti alaptanterv alapjául szolgáló - Kodálykoncepciót, többen hangsúlyozták, hogy a nem tagozatos osztályokban részben az alacsony óraszámból eredően nem tud érvényesülni a Kodály-féle pedagógia, mindössze a tanárok számára szolgál iránymutatásként a tanítás során.

„Elsősorban a Kodályt ismerem, valamennyire Dalcroze és Orff módszerét. A tanítás során Kodály módszer sémája alapján a sajátomat használom. A legjobb módszer, ha néha kevered a módszereket. A Kodály-koncepció kapcsán elsősorban a gondolatok a fontosak, nem a módszer az oktatásban. A nem tagozatos osztályokban nem beszélhetünk Kodály-módszerről, teljesen értelmetlennek találom, mivel heti egy órában nem lehet megtanulni szolmizálni. A tagozaton a Kodály-módszer - különösen alsó tagozaton - nagyon fontos. 5. évfolyamban még talán, azonban a 6. osztálytól kezdve a kórusmüvek elviszik az időt." (30 éves általános iskolai ének-zene tanár)

„A Kodály- és az Orff-módszert ismerem. Ez a kettő nagyon hasonlít egymásra, hiszen mindkettő koncentrál a ritmus fejlesztésére. A tagozatos osztályokban szólamfelmondás történik, náluk szigorúan veszem a hanghibákat. Ugyanakkor maximum hármas lehet a legrosszabb érdemjegy. Míg a tanuló nem tudja teljesíteni, addig felel az adott kórusműből. A normál osztályokban teljesen más a helyzet, itt nem vagyok szigorú. Vannak tehetséges és kevésbé tehetséges gyerekek. Sajnos sok tanulónak nem jó a hallása. Ennek ellenére igyekszem 4-es és 5-ös jegyeket adni." (35 éves általános iskolai ének-zene tanár)

„A Kodály- és az Orff-módszert ismerem, s amennyire lehet használom az órákon. Ugyanakkor úgy vélem a szolmizálás a gimnáziumban nem tud eszközzé válni, ha már alapszinten nem kerül befogadásra. Gimnáziumban meg lehet tanulni, de nagyon késő elkezdeni." (46 éves nem tagozatos gimnáziumban tanító ének-zene tanár)

„A Kodály-féle zenepedagógiát ismerem, de őszintén szólva nem igazán kutakodok a többi módszer iránt. A gimnáziumban heti egy órában a zenetörténeti ismeretekre, az éneklésre és az élményre koncentrálunk, nincs szolmizálás." (43 éves gimnáziumi ének-zene tanár)

Azok a tanárok, akik nem neveztek meg egyetlen zenepedagógiai módszert sem az előzetes tanáraiktól kapott ismereteket, valamint az előzetes tanulmányaik és tapasztalataik alapján kialakított „saját” tanítási technikájukat és módszereiket emelték ki. 
„A magamé. Az előző tanáraimtól tanultak alapján tanítok.” (53 éves nevelőtanár)

„Amit tanultunk annak idején... Nem csoportosan, hanem frontálisan dolgozunk az énekórán." (49 éves nevelőtanár)

„A saját magam által kitalált játékos feladatok segítségével tanítok, például legós ritmusfeladatok, a hangközök tanulásához a hangköz hőmérő játékot alkalmazom és így tovább." (53 éves nem tagozatos iskolában tanító ének-zene tanár)

Az eredményekből arra következtethetünk, hogy nem minden tanár követi és veszi szigorúan a kodályi alapelveket az énektanítás során. Sőt, némely tanár (2 általános iskolai ének-zene tanár, 3 nevelőtanár) említést sem tett a Kodály-módszer iskolai alkalmazásáról az interjúk folyamán. Ezzel szemben azok a tanárok, akik bár fontosnak tartották a kodályi gondolatokat elsősorban az alacsony óraszámra való tekintettel vonták kétségbe a koncepció iskolai alkalmazásának megvalósíthatóságát. Az eredményekből kirajzolódott, hogy a zenei készségfejlesztés alapvetően a tagozatos osztályokban érvényesül, míg a nem zenetagozatos osztályokban a szolmizálás, a zenei írás-olvasás, hallásfejlesztés, s ebből kifolyólag a tiszta éneklés fejlesztése aligha tud megvalósulni.

\section{Összegzés}

Jelen tanulmány célja, hogy megvizsgálja az ének-zene tantárgy helyzetét, valamint, hogy feltárja az iskolai zeneoktatást megnehezítő problémákat, illetve hogy tisztázza a kodályi gondolatokon nyugvó célkitüzéseket és azok megvalósításának szigorúságát az iskolai gyakorlatban.

A vizsgálat során meginterjúvolt 15 ének-zene tantárgyat tanító pedagógus számolt be az ének-zene iskolai tantárgyak között betöltött alárendelt szerepéről. A megkérdezett tanárok elmondása szerint a zeneoktatás eredményességét hátráltató legsúlyosabb problémák az óraszámok és a tananyag aránytalanságából, a tanulók zenetanulás iránti közömbösségéből, valamint a tanulók tudásbeli hiányosságaiból és az énekléshez füződő alacsony önbecsüléséből fakadnak. Mindemellett az eredmények azt mutatják, hogy a tanároknak az új tananyag leadása, valamint a zenei ismeretek és élmények együttes biztosítása mellett a tanulók zenei hiányosságainak pótlására is kellő időt kell szánniuk. Ennek következtében számos tanár a diákok képessége és előzetes zenei tudása alapján határozza meg az órák tananyagát, amely viszont sok esetben nincs összhangban az elöírt tananyaggal.

Az iskolai zeneoktatás megújítása tekintetében a tanári interjúk eredményei egy gyermekközpontú zenei tananyag újragondolását és modernizálását, új akkreditált tankönyvek összeállítását és megjelentetését vetik fel. Ugyanakkor a kutatásban résztvevő ének-zene szakos tanárok egy része a tanulók tudásbeli hiányosságainak csökkentését és/vagy elkerülését az álta- 
lános iskola 1. osztályától történő ének-zene szakos tanárok alkalmazásában látták. Ezen túlmenően a megkérdezett pedagógusok fontosnak tartották az óraszámok és a tananyag összeegyeztethetőségének helyreállítását, valamint a szabad tankönyvválasztás lehetőségét. Az eredményekből kirajzolódik, hogy az ének-zenéből történő számonkérés szigorúsága elsősorban a zenetagozatos osztályokban jellemző. Mindemellett a Kodály módszer iskolai alkalmazása szintén kizárólag ezekben az osztályokban tud érvényesülni.

Kutatási eredményeink az iskolai ének-zene tantárgy hanyatló állapotának megértéséhez és az énektanítást nehezítő problémák feltárásához járulhatnak hozzá. Mindemellett jelen vizsgálat az ének-zene tantárgyat tanító tanárok, valamint a zenei tananyagot összeállító szakemberek munkáját igyekszik segíteni.

\section{Irodalom}

Asztalos, A. (2018). Beéneklés az énekzene órákon és a gyermekkari próbákon. Parlando, 60(6), 1-10.

Bónis, F. (2007). Kodály Zoltán Visszatekintés I., II., III. - Összegyüjtött beszédek, írások, nyilatkozatok. Argumentum Kiadó.

Böddi, Zs., Keszei, B., Serfőző, M., \& Dúll, A. (2015). A megfigyelés kutatásmódszertana - Interakciók megfigyelése integrált és inkluzív óvodai környezetben. Gyermeknevelés, 3(2), 29-50.

Bruckner, A. (1999). Énekelni jó(l)! Kodály Intézet.

Csengery, K. (2014). Az iskolai zeneoktatás válsága - Nemes László Norbert zenekultúráról, zenepedagógiáról. Zenekar - A Magyar Szimfonikus Zenekarok Szövetségének, valamint a Magyar Zenemüvészek és Táncmüvészek Szakszervezetének közös lapja. 19(2), 20-23. https://zene-kar.hu/wp-content/ uploads/2017/12/zenekar_2014_2_web.pdf (2020.06.17.)

Csíkos, Cs. (2012). Melyik a kedvenc tantárgyad? Tantárgyi attitűdök vizsgálata a nyíltvégű írásbeli kikérdezés módszerével. Iskolakultúra, 22(1), 3-13. http://real. mtak.hu/56688/1/EPA00011_Iskolakultura_2012_01_003-013.pdf (2020.06.17.)

Dohány, G. (2009). Zenei élmény az énekórán? Iskolakultúra, 19(3), 70-79. http:// misc.bibl.u-szeged.hu/45541/1/iol_2009_002_070-079.pdf (2020.06.17.)

Dohány, G. (2013). A zenei müveltség és az ének-zene tanulásával kapcsolatos háttérváltozók összefüggéseinek empirikus vizsgálata a középiskolás tanulók körében. SZTE BTK Neveléstudományi Doktori Iskola, PhD értekezés. http:// doktori.bibl.u-szeged.hu/1943/1/Disszertacio_dohany.pdf (2020.06.17.)

Dohány, G. (2014). Háttérváltozók és a zenei műveltség összefüggéseinek vizsgálata középiskolások körében. Magyar Pedagógia, 114(2), 91-114. Magyar Pedagógia a Magyar Tudományos Akadémia Pedagógiai Bizottságának folyóirata. http:// www.magyarpedagogia.hu/document/2_Dohany_MP1142.pdf

Gönczy, L. (2009). Kodály-koncepció: a megértés és alkalmazás nehézségei Magyarországon. Magyar Pedagógia, 109(2), 169-185. 
Magyar Pedagógia a Magyar Tudományos Akadémia Pedagógiai Bizottságának folyóirata. (2020.06.17.) http://magyarpedagogia.hu/document/Gonczy_MP1092.pdf

Janurik, M. (2007). Áramlatélmény az iskolai ének-zeneórákon. Magyar Pedagógia, 107(4), 295-320. Magyar Pedagógia a Magyar Tudományos Akadémia Pedagógiai Bizottságának folyóirata. http://magyarpedagogia.hu/document/ Janurik_MP1074.pdf (2020.06.17.)

Janurik, M. (2008). Betöltik-e szerepüket az ének-zeneórák a mai oktatásban? Iskolakultúra, 18(9-10), 107-117. http://www.iskolakultura.hu/index.php/ iskolakultura/article/view/20788 (2020.06.17.)

Janurik, M. \& Józsa, K. (2018). Az iskolai zenetanulás iránti motivációt alakító néhány tényező. Gyermeknevelés, 6(2) 5-17. https://doi.org/10.31074/gyn2018214

Janurik, M. \& Pethő, V. (2009). Flow élmény az énekórán: a többségi és Waldorfiskolák összehasonlító elemzése. Magyar Pedagógia, 109(3), 193-226. Magyar Pedagógia a Magyar Tudományos Akadémia Pedagógiai Bizottságának folyóirata. http://www.magyarpedagogia.hu/document/Janurik_MP1093.pdf (2020.06.17.)

L. Nagy, K. (2002). Az ének-zene tantárgy helyzete és fejlesztési feladatai. Új Pedagógiai Szemle, 52(11) 73-83. Elektronikus Periodika Archívum és Adatbázis (EPA) - Országos Széchényi Könyvtár (OSZK). https://epa.oszk. hu/00000/00035/00065/2002-11-hk-LNagy-Enek.html (2020.06.17.)

L. Nagy, K. (2003). Az ének-zene tantárgy helyzete egy kérdőives felmérés tükrében. Oktatási Hivatal. http://ofi.hu/az-enek-zene-tantargy-helyzete-egy-kerdoivesfelmeres-tukreben (2020.05.13.)

Laczó, Z. (2010). Leszállóágban a zeneoktatás? Fidelio. https://fidelio.hu/klasszikus/ leszalloagban-a-zeneoktatas-87829.html (2020.05.25.)

Mannheim, Karl (1969). A nemzedéki probléma. Ifjúságszociológia.

Nagy, Á. \& Kölcsey, A. (2017). Mit takar az alfa-generáció? Metszetek Társadalomtudományi folyóirat, 6(3), http://metszetek.unideb.hu/files/ metszetek_201703_02.pdf (2020.02.06.)

Nemzeti alaptanterv (2020). A Nemzeti alaptanterv kiadásáról, bevezetéséről és alkalmazásáról. Korm. Rendelet. Magyar Közlöny, 2020.3. https://magyarkozlony. hu/dokumentumok/f06f631fa3d60f9bef336bbc648efe704d0df73c/megtekintes (2020.04.29.)

Pál, E. \& Törőcsik, M. (2013). A Z generációról - Irodalmi áttekintés. Pécsi Tudományegyetem - „Tudománykommunikáció a Z generációnak” projekt honlapja. http://www.zgeneracio.hu/getDocument/4252 (2020.06.17.)

Pintér, T. (2017). A mindennapos éneklés margójára. Parlando, 59. 1-16. https:// www.parlando.hu/2017/2017-3/PinterTunde-Parlando.pdf (2020.06.17.)

Pintér, T. (2018). A zenei nevelés megítélése általános iskolás tanulók körében. In Váradi, J. \& Szücs, T. (Eds.), A zenepedagógia múltja, jelene és jövője (pp. 205 -219.) Debreceni Egyetemi Kiadó. 
Pintér, T. K. (2020). Az iskolai és iskolán kívüli zene megitélésének empirikus vizsgálata tanulók, szülők és tanárok körében. Akadémiai Kiadó, Közlésre benyújtva.

Pintér, T. \& Csíkos, Cs. (2020). Tanulók, szülők és tanárok perspektívái az iskolai zenei nevelés céljáról és feladatáról. Iskolakultúra, Közlésre benyújtva.

Sántha, K. (2007). A kvalitatív metodológiai követelmények problémái. Iskolakultúra, 17(6-7), 168-177. http://www.iskolakultura.hu/index.php/iskolakultura/article/ view/20650 (2020.06.17.)

Sántha, K. (2009). Bevezetés a pedagógiai kutatás módszertanába. Eötvös József Könyvkiadó.

Szabó, H. (1996). Az énektanárképzés helyzetéről. Parlando, 38(1), http://www. parlando.hu/SzaboHelga1.html (2020.06.17.)

Szokolszky, Á. (2004). Kutatómunka a pszichológiában. Metodológia, módszerek, gyakorlat. Osiris Kiadó.

Szőnyi, E. (1971). A Summary of the Kodaly Method: Part One. Australian Journal of Music Education, 8, 31-37. https://search.informit.com.au/documentSumma ry;dn=874215466049597;res=IELHSS_(2020.06.16.)

Tari, A. (2010). Y generáció. Jaffa Kiadó.

Tari, A. (2011). Z generáció. Jaffa Kiadó.

Tóbi, I. (2013). Tudománykommunikáció a Z generációnál. Pécsi Tudományegyetem - „Tudománykommunikáció a Z generációnak” projekt honlapja. www. zgeneracio.hu/getDocument/801 (2020.02.06.)

Tóth, E. (2015). Az országos kompetenciamérés hatása a tanítási munkára pedagógusinterjúk alapján. Magyar Pedagógia, 115(2), 115-138. https://doi. org/10.17670/MPed.2015.2.115

Turmezeyné, H. E. \& Balogh, L. (2009). Zenei tehetséggondozás és képességfejlesztés. Kocka Kör Tehetséggondozó Kulturális Egyesület és Faculty of Central European Studies, Constantine the Philosopher University.

Türkmen, E. F. \& Göncü, I. Ö. (2018). The challenges encountered in the application of Kodály method in Turkey. Journal of Education and Training Studies. 6(9), 39-45. https://doi.org/10.11114/jets.v6i9.3309

Wayman, V. E. (2004). An Exploratory Investgation of Three Middle School General Music Students' Beliefs about Music Education. Bulletin of the Council for Research in Music Education, 160. 26-37. JSTOR. https://www.jstor.org/ stable/40319216 (2020.06.17.) 
Pintér, T. K.

\section{Challenges and difficulties of Hungarian school music education among elementary and secondary school music teachers}

The aim of this article is to define the challenges and difficulties of Hungarian school music ed-ucation. Totally, 15 music teachers who taught music in special music and non-music classes were interviewed. Results indicated that school music education have been influenced by many factors such as (1) disproportion of timing and music curriculum, (2) students' indifferent atti-tudes toward music lessons, (3) the lack of musical knowledge of the students, (4) pupils' nega-tive attitudes toward singing and their low self-esteem, (5) generation gap between students and teachers, (6) the lack of positive feedback for the teacher, as well as (7) the lack of equipment in the music classroom. On the other hand, results also pointed out that Kodály method can fulfill its requirement in special music classes exclusively, but it can be also observed a declining state of school music education in these classes.

Keywords: school music, music teacher, interview, attitude, Kodály method

Pintér Tünde Kornélia: ORCID: 0000-0003-0167-6443 